\title{
Spatiotemporal distribution of seasonal snow water equivalent in High-Mountain Asia from an 18-year Landsat-MODIS era snow reanalysis dataset
}

\author{
Yufei Liu ${ }^{1}$, Yiwen Fang ${ }^{1}$ and Steven A. Margulis ${ }^{1}$
}

$5{ }^{1}$ Department of Civil and Environmental Engineering, University of California, Los Angeles, CA, USA Correspondence to: Steven A. Margulis (margulis@ seas.ucla.edu)

\begin{abstract}
Seasonal snowpack is an essential component in the hydrological cycle and plays a significant role in supplying water resources to downstream users. Yet the snow water equivalent (SWE) in seasonal snowpacks, and its space-time variation, remains highly uncertain, especially over mountainous areas with complex terrain and sparse observations, such as

10 in High-Mountain Asia (HMA). In this work, we assessed the spatiotemporal distribution of seasonal SWE, obtained from a new 18-year HMA Snow Reanalysis (HMASR) dataset, as part of the recent NASA High-Mountain Asia Team (HiMAT) effort. A Bayesian snow reanalysis scheme previously developed to assimilate satellite derived fractional snow-covered area (fSCA) products from Landsat and MODIS platforms has been applied to develop the HMASR dataset (at a spatial resolution of 16 arc-second ( $500 \mathrm{~m})$ and daily temporal resolution) over the joint Landsat-MODIS period covering Water

15 Years (WYs) 2000-2017. Based on the results, the HMA-wide total SWE volume is found to be around $163 \mathrm{~km}^{3}$ on average and ranges from $114 \mathrm{~km}^{3}$ (WY2001) to $227 \mathrm{~km}^{3}$ (WY2005) when assessed over 18 WYs. The most abundant snowpacks are found in the northwestern basins (e.g. Indus, Syr Darya and Amu Darya) that are mainly affected by the westerlies, accounting for around $66 \%$ of total seasonal SWE volume. When examining the elevational distribution over the HMA domain, seasonal SWE volume peaks at mid-elevations (around $3500 \mathrm{~m}$ ), with over $50 \%$ of the volume stored above 3500

$20 \mathrm{~m}$. This work brings new insight into understanding the climatology and variability of seasonal snowpack over HMA, with the regional snow reanalysis constrained by remote sensing data, providing a new reference dataset for future studies of seasonal snow and how it contributes to the water cycle and climate over the HMA region.
\end{abstract}

\section{Introduction}

The High-Mountain Asia (HMA) region consists of the major mountain ranges and headwaters of the largest rivers in Asia.

25 It features extremely high elevation, complex topography and significant glacier and snow cover. In HMA, glacier melt and snowmelt are vital to the hydrological cycle and water supply, as they feed the major regional rivers with over one billion people living downstream (Barnett et al., 2005; Bookhagen and Burbank, 2010; Immerzeel et al., 2010; Immerzeel and Bierkens, 2012; Lutz et al., 2014; Armstrong et al., 2019; Scott et al., 2019; Immerzeel et al., 2020). 
https://doi.org/10.5194/tc-2021-139

Preprint. Discussion started: 17 May 2021

(c) Author(s) 2021. CC BY 4.0 License.

\section{(c) (i)}

Even though both seasonal snow and glaciers are crucial to hydrology and water availability, seasonal snow has arguably

received less attention than glaciers in the HMA region. Many studies have addressed the status and changes in glaciers over HMA (e.g. Bolch et al., 2012; Kääb et al., 2012; Sorg et al., 2012; Yao et al., 2012; Lutz et al., 2014; Bolch et al., 2019; Rounce et al., 2020; Shean et al, 2020). For seasonal snow, previous studies have examined the snow extent (e.g. Dahe et al., 2006; Pu et al., 2007; Immerzeel et al., 2009; Tahir et al., 2011; Basang et al., 2017; Wang et al., 2017; Notarnicola 2020), or snow mass and snow depth (e.g. Dahe et al., 2006; Che et al., 2008; Terzago et al., 2014; Dai et al., 2017; Stigter et al., 2017;

35 Smith and Bookhagen, 2018. 2020; Ahmad et al., 2019; Kirkham et al., 2019; Xue et al., 2019). In the current literature involving seasonal snow, most of the studies have focused on snow covered area (or extent, which is readily available from satellite-borne remote sensing) instead of snow mass, or have been applied at relatively localized scales or coarse scales. The seasonal snow water storage and its spatiotemporal distribution at finer scales are highly uncertain in HMA, primarily due to the lack of in situ observations and fine-scale snow water equivalent (SWE) datasets over this large domain (Takala et al.,

40 2011; Kirkham et al., 2019). In fact, accurately estimating SWE (at scales of a few kilometers) remains a great challenge worldwide, and it is even more difficult in mountainous regions due to the terrain complexity (Lettenmaier et al., 2015; Dozier et al., 2016; Bormann et al., 2018).

In situ measurements are usually expensive and difficult to install and maintain in HMA and are mostly located in low-lying valleys, thus resulting in a sparse and potentially nonrepresentative network (Winiger et al., 2005; Palazzi et al., 2013; Dozier et al., 2016; Kirkham et al., 2019). In recent decades, satellite observations can provide large-scale estimates of some snowpack properties. However, most of these measured properties, such as snow-covered area (SCA) based on visible and near infrared bands (e.g. Dozier, 1989, Hall et al., 2002, Painter et al., 2009), are only indirectly related to snow mass. While SWE and snow depth can be directly estimated from passive microwave sensors (using retrieval algorithms based on the brightness temperature; e.g. Chang et al., 1987), these estimates are at coarse spatial resolution (e.g. $25 \mathrm{~km}$ ), and are 50 generally negatively biased in deep snowpacks (Takala et al., 2011; Dozier et al, 2016). Recent applications of C-band synthetic aperture radar (SAR) techniques show promise for snow depth retrieval (Lievens et al., 2019) but are available only over recent years and do not directly provide SWE.

Global atmospheric reanalysis products provide another approach to large-scale SWE estimates as by-products of their land surface schemes. Examples include the Global Land Data Assimilation System (GLDAS, Rodell et al., 2004), Modern-Era

55 Retrospective analysis for Research and Applications (MERRA, Rienecker et al., 2011; MERRA-2, Gelaro et al., 2017), European Centre for Medium-Range Weather Forecasts (ECMWF) Re-Analysis products (ERA-Interim, Dee et al., 2011; ERA5, Hersbach et al., 2020), High Asia Refined analysis (HAR, Maussion et al., 2011; 2014), Japanese 55 -year Reanalysis (JRA-55; Kobayashi et al., 2015), and others. SWE estimates in these datasets are found to be generally consistent in their interannual and seasonal variations, but can differ significantly in their magnitudes when evaluated over different regions 60 (Mudryk et al., 2015; Wrzesien et al., 2019), where the uncertainties come from different land surface models and meteorological inputs (Mudryk et al., 2015; Mortimer et al., 2020; Kim et al., 2021). In addition, most reanalysis datasets are not specifically designed for SWE estimation, and usually do not assimilate snow observations. Bian et al. (2019) found 
https://doi.org/10.5194/tc-2021-139

Preprint. Discussion started: 17 May 2021

(c) Author(s) 2021. CC BY 4.0 License.

\section{(c) (i)}

many reanalysis datasets overestimate SWE compared to ground observations in the Tibetan Plateau, although part of the differences may come from inconsistent spatial resolution and elevations between in situ and gridded datasets. The performance of these large-scale reanalysis datasets over the full HMA domain has not been fully assessed due to the sparse and uneven in situ station network.

Recent works have contributed to the development of SWE (or snow depth) estimates covering the HMA region based on passive microwave (e.g. Talaka et al., 2011; Smith and Bookhagen, 2016; Dai et al., 2017; Pulliainen et al., 2020) or active microwave measurements (Lievens et al., 2019). Machine learning approaches have been explored to predict SWE using passive microwave data (e.g. Ahmad et al., 2019). Moreover, some studies have explicitly merged snow observations with modeling via data assimilation (DA) to provide more realistic SWE estimates, which is an effective approach in reducing SWE uncertainties especially over the mountains (Largeron et al., 2020). For example, the JRA-55 product assimilates both ground snow depth and satellite retrieved snow cover observations (Kobayashi et al., 2015), and its snow depth estimate is found to have good performance when evaluated over the Tibetan Plateau (Orsolini et al., 2019). The ERA5 dataset also employs in situ snow depth and satellite observed snow cover (limited to elevation below $1500 \mathrm{~m}$ ) in its snow assimilation scheme. Xue et al. (2019) showed that assimilating SCA products can improve SWE estimates in the HMA region. Passive microwave retrieved SWE along with ground snow depth observations are also assimilated in the GlobSnow (Talaka et al., 2011; Pulliainen et al., 2020) products to provide SWE and snow extent estimates, with mountain areas of high terrain complexity masked out. These are promising approaches to improve the accuracy in SWE estimates over HMA, yet currently there is still a need for large scale SWE datasets at higher resolutions, over longer periods and covering mountainous areas in this region.

To better understand the spatiotemporal pattern and variability in seasonal snowpack over HMA, the so-called HighMountain Asia Snow Reanalysis (HMASR; Liu et al., 2021) dataset, available for the joint Landsat-MODIS era between Water Years (WYs) 2000 to 2017 (which will be extended to present in later versions), was developed as part of the NASA High-Mountain Asia Team (HiMAT) activities. HiMAT is a multi-investigator effort in developing new datasets to understand cryosphere variability over HMA (Osmanoglu et al., 2017). The HMASR dataset provides daily estimates of SWE, fractional snow-covered area (fSCA) and other snow variables, at a 16 arc-second ( $\sim 500 \mathrm{~m})$ resolution. SWE estimates are derived by assimilating fSCA from Landsat and MODIS platforms using a previously developed snow reanalysis framework (Margulis et al., 2019), where the method has been shown in previous applications to provide realistic SWE estimates over mountainous domains in the Sierra Nevada (Margulis et al., 2016) and Andes (Cortés and Margulis, 2017). The HMASR aims to fill the spatiotemporal gaps in existing SWE datasets and allow for better characterization of the distribution and changes in seasonal snow storage, and provide insights into the hydrologic cycle and water availability over HMA. Using this dataset, the spatial distribution of SWE climatology is examined at annual and seasonal scales over the HMA region, covering the highest mountain ranges and the Tibetan Plateau in Asia. Integrated SWE volumes over the full 95 HMA domain and over the major river basins (e.g., Syr Darya, Amu Darya, Indus, Ganges-Brahmaputra, Yangtze, Yellow), and their variation with elevation, are also quantified in this work. The following scientific questions are addressed: 
https://doi.org/10.5194/tc-2021-139

Preprint. Discussion started: 17 May 2021

(c) Author(s) 2021. CC BY 4.0 License.

(c) (i)

1) How much seasonal snow is stored across HMA?

2) How is this snow storage distributed spatially across the major watersheds of HMA?

3) What is the seasonal and interannual variability in amount of snow storage over HMA?

4) How is the amount of snow distributed across elevation?

\section{Data and method}

This section describes the data and methods used in this study. Section 2.1 introduces the study domain, including the major river basins and mountain ranges in the region. Section 2.2 and 2.3 provide a brief description of the reanalysis method, input data and models used in the development of the HMASR. Finally, a non-seasonal snow and ice mask applied to mask out semi-permanent snow and ice for the assessment of seasonal snow is explained in Sect. 2.4.

\subsection{HMA domain}

The HMA domain used in this work is bounded from $27^{\circ} \mathrm{N}$ to $45^{\circ} \mathrm{N}$, and from $60^{\circ} \mathrm{E}$ to $105^{\circ} \mathrm{E}$ (Fig. 1), covering the highest mountain ranges and plateaus (Tien Shan, Pamir, Hindu Kush, Karakoram, Himalayas, and Tibetan Plateau), as well as the headwaters of the main river basins (Syr Darya, Amu Darya, Indus, Ganges-Brahmaputra, Yangtze, and Yellow). Winter

110 westerlies and the summer monsoon are the major moisture sources in this region, significantly influencing the spatiotemporal patterns in snowfall and glacier mass balance. More specifically, the northern and western HMA is dominated by westerlies and receives abundant winter snowfall, while the southern and eastern HMA is dominated by the Indian monsoon from June to September and receives a considerable amount of summer snowfall; the eastern edges of HMA are affected by the East Asia monsoon but with limited impact (Bookhagen and Burbank 2010; Yao et al., 2012; Bolch et al.,

115 2019). Note that in HMASR, outputs are provided for each regular $1^{\circ}$ by $1^{\circ}$ latitude-longitude tile (within which a regular computational grid of 16 arc-seconds is used), and only tiles likely to contain snow (with a tile-averaged elevation above $1500 \mathrm{~m}$ ) were selected and processed in the dataset (Fig. 1). 
https://doi.org/10.5194/tc-2021-139

Preprint. Discussion started: 17 May 2021

(C) Author(s) 2021. CC BY 4.0 License.
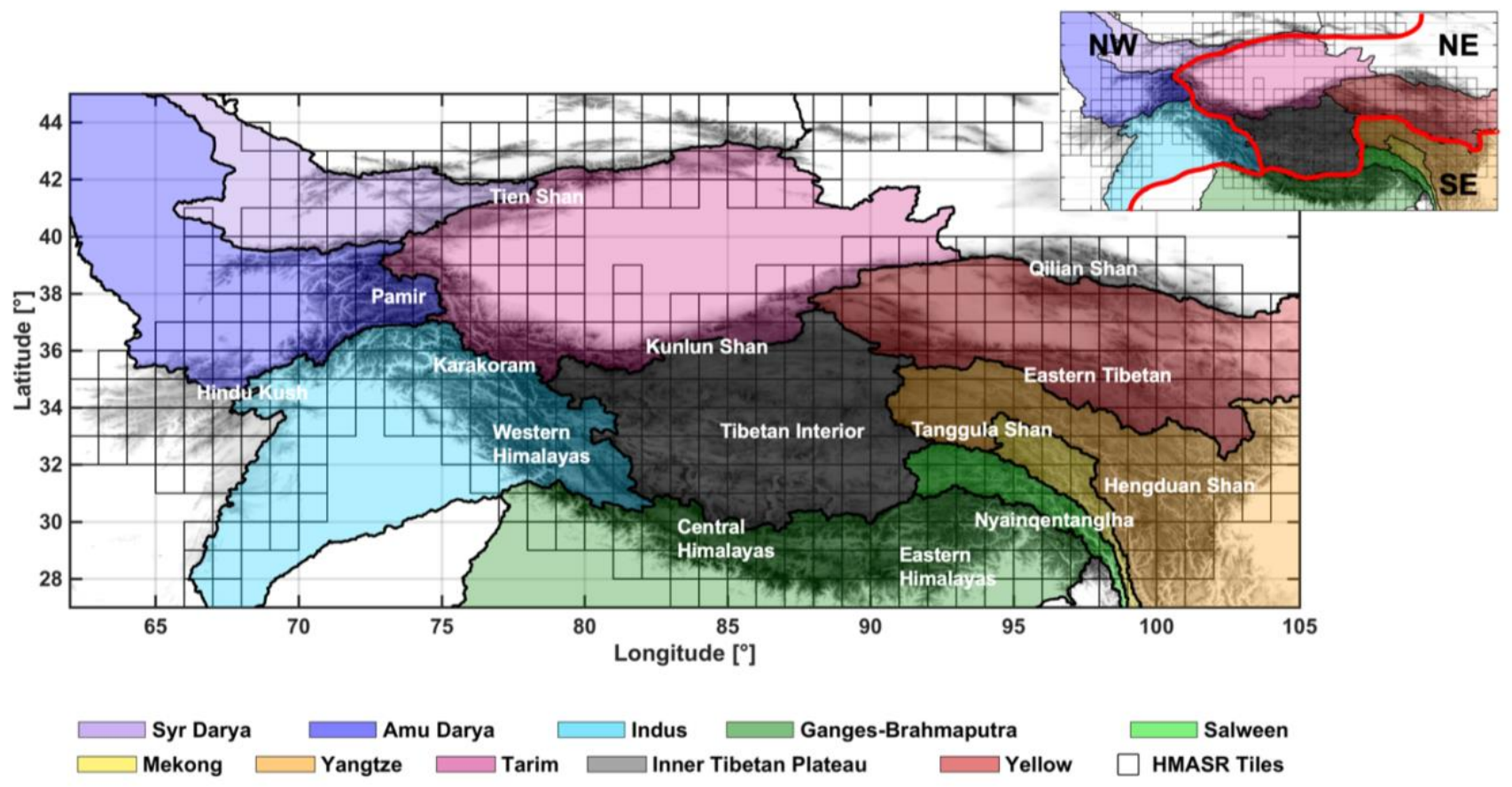

Figure 1: Map of HMA domain with HMASR tiles marked with black boxes. Major watersheds are delineated and colored on the map based on HydroSHEDS (Lehner et al., 2008). Major mountain ranges are labeled with reference to Bolch et al. (2019). A division of the HMA domain into Northwestern (NW), Northeastern (NE) and Southeastern (SE) sub-regions, which are used for descriptive purposes in this study, is shown in the inset.

For convenience in presenting results herein, the HMA domain was divided into three large subregions, namely the Northwestern (NW), Southeastern (SE) and Northeastern (NE) subregions (Fig. 1). Major river basins are identified in each subregion, namely those located in NW (Syr Darya, Amu Darya and Indus), in SE (Ganges-Brahmaputra, Salween, Mekong and Yangtze), and in NE (Tarim, Inner Tibetan Plateau and Yellow). Similarly, the major mountain ranges are also identified in each subregion, namely those located in NW (e.g. Tien Shan, Pamir, Hindu Kush, Karakoram, western Himalayas), in SE (e.g. central and eastern Himalayas, Nyainqentanglha, Tanggula Shan and Hengduan Shan), and in NE (e.g. Kunlun Shan, Tibetan Interior, Eastern Tibetan and Qilian Shan), and are labelled in Fig. 1.

\subsection{Snow reanalysis scheme}

A previously developed snow reanalysis methodology (Margulis et al., 2019) is employed in deriving the HMASR. For brevity, only the key details are repeated here. Prior model and measurement estimates are obtained via the coupled Simplified Simple Biosphere model, version 3 snow model (SSiB3; Sun and Xue, 2001; Xue et al., 2003) and the Liston (2004) snow depletion curve (SDC). Specifically, an ensemble approach is used whereby the model generates prior estimates

135 of snow states (i.e. SWE, snow depth, etc.) and predicted measurements (fSCA) and their uncertainties. Meteorological 
https://doi.org/10.5194/tc-2021-139

Preprint. Discussion started: 17 May 2021

(c) Author(s) 2021. CC BY 4.0 License.

forcing inputs are bias-corrected, downscaled to the modeling grid (16 arc-second) and perturbed with uncertainty in the ensemble approach, using the methods described in Durand et al. (2008) and Girotto et al. (2014).

To constrain the prior snow estimates on the remotely sensed fSCA observations, a Bayesian update is performed using the Particle Batch Smoother (PBS; Margulis et al., 2015) approach, resulting in posterior snow estimates that are more consistent

140 with the batch of observed fSCA in a given water year. More details on the method are described in Margulis et al. (2015) and Margulis et al. (2019). The lack of in situ SWE data over HMA prevents a thorough verification of the HMASR. However, previous applications of the snow reanalysis method in similarly complex terrain in the Sierra Nevada of the Western U.S. and the South American central Andes thoroughly compared reanalysis estimates vs. in situ and airbornederived SWE data. Performance in both domains were positive relative to in situ data with values of mean error, root-mean-

145 squared error and correlation coefficients of: $\sim 3 \mathrm{~cm}, 13 \mathrm{~cm}$ and 0.95 for the Sierra Nevada (Margulis et al., 2016) and $\sim 1$ cm, $29 \mathrm{~cm}$ and 0.73 for the Andes (Cortés and Margulis, 2017), respectively. In Margulis et al. (2019), comparison with the Airborne Snow Observatory (ASO) data yielded similar results (mean error, root-mean-squared error, and correlation coefficients of $\sim 5 \mathrm{~cm}, 23 \mathrm{~cm}$, and 0.84 ).

\subsection{Input data acquisition and processing}

\section{$150 \quad$ 2.3.1 Meteorological, topographic and land cover data}

In HMASR, prior surface meteorological inputs were obtained from MERRA-2 at its raw resolution $\left(0.5^{\circ}\right.$ by $0.625^{\circ}$ latitude-longitude), including precipitation, air temperature, solar radiation, specific humidity, surface pressure and wind speed. The uncertainty models and their parameters used to perform bias-correction and uncertainty perturbation are specified in Margulis et al. (2019) for the HMA region, except that prior ensemble precipitation is perturbed by a lognormal

155 distribution with mean of 1.54 and coefficient of variation (CV) of 0.83 based on the results from Liu and Margulis (2019). Digital elevation model (DEM) data were obtained from the Shuttle Radar Topography Mission (SRTM, http://www2.jpl.nasa.gov/srtm/) 1 arc-second product, and aggregated to 16 arc-second ( $\sim 500 \mathrm{~m})$ resolution. Gaps in DEM data were filled by the Advanced Spaceborne Thermal Emission and Reflection Radiometer (ASTER) Global Digital Elevation Model (GDEM, version 2) 1 arc-second product (https://asterweb.jpl.nasa.gov/). Land cover data were obtained from the AVHRR global land cover classification dataset (Hansen et al., 2000). Forest cover information was obtained from the Tree Canopy Cover (TCC) product containing the Landsat Vegetation Continuous Fields (https://lcluc.umd.edu/metadata/global-30m-landsat-tree-canopy-version-4; Sexton et al., 2013).

\subsection{2 fSCA data}

The fSCA observations used to condition prior snow estimates were retrieved from Landsat and MODIS platforms, for their 165 joint period of WYs 2000 to 2017 (e.g. where WY2000 corresponds to October 1, 1999 - September 30, 2000). The (nadirviewing) Landsat-based fSCA data were obtained from Landsat 5, 7 and 8 satellites, retrieved using a spectral unmixing 
https://doi.org/10.5194/tc-2021-139

Preprint. Discussion started: 17 May 2021

(C) Author(s) 2021. CC BY 4.0 License.

algorithm (Painter et al., 2003; Cortés et al., 2014), available at $30 \mathrm{~m}$ and every 16 days (excluding cloudy days). The (nadirand off-nadir-viewing) MODIS-based fSCA data were obtained from the MODIS Snow Covered Area and Grain size (MODSCAG) product (Painter et al., 2009), available daily at $500 \mathrm{~m}$, with a viewing angle between $0^{\circ}$ and $55^{\circ}$.

170 The HMASR dataset used fSCA from both satellites to increase the number of observations with good quality, because of the frequent cloud contamination in some areas of HMA (Margulis et al., 2019). Cloud screening was performed for both Landsat and MODIS images (as illustrated in Margulis et al., 2019), which were then aggregated to the modeling resolution (16 arc-second). For MODSCAG, erroneous fSCA observations are removed when the viewing angles are significantly offnadir, and a CDF-matching step is applied to reconcile the inconsistency with Landsat images. More details about the fSCA

175 data used in HMASR are described in Margulis et al. (2019).

It is worthwhile to note that the fSCA data availability is significantly affected by cloud contamination in some areas of HMA region, especially during the monsoon seasons (June-September) where fSCA measurements are limited over regions such as the Himalayas (Fig. 2). The lack of abundant fSCA data can be a potential limitation in assimilating fSCA observations for these monsoon-affected regions, and therefore leads to higher uncertainty and potential errors in posterior SWE estimates (i.e. where in the limit of no available observations, the posterior will, by construct, equal the prior estimate).

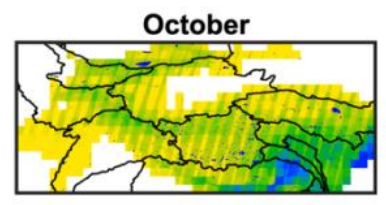

February

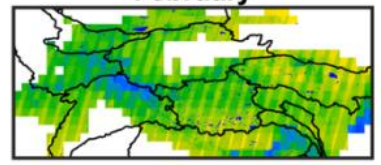

June

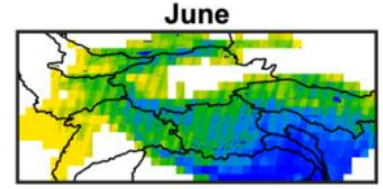

November

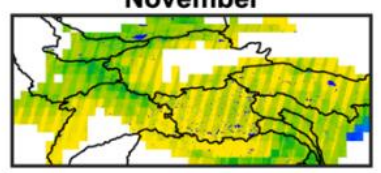

March

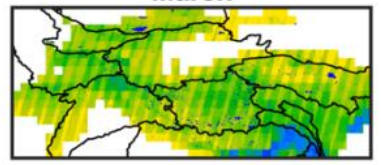

July

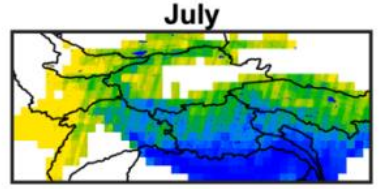

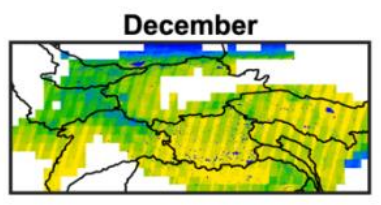

April

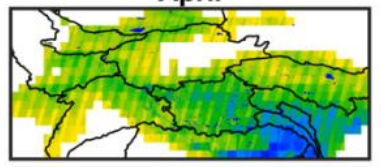

August

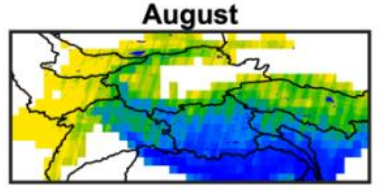

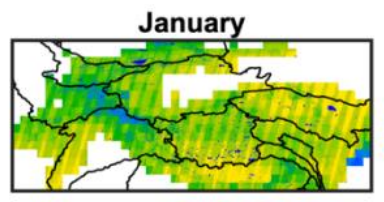

May

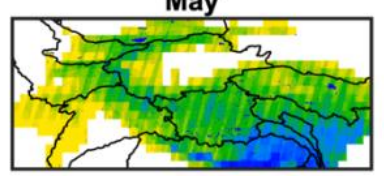

September

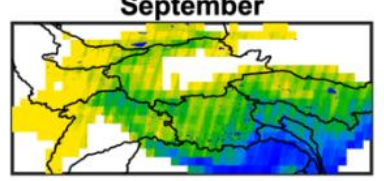

Available MODSCAG observations

$\begin{array}{llllll}0 & 1 & 2 & 3 & 4 & 5\end{array}$

Figure 2: Monthly total number of available (near-nadir) MODSCAG measurements averaged over 18 years, with cloud and viewing angle screening. Landsat measurements supplement these MODIS-derived measurements.

\subsection{Non-seasonal snow and ice mask}

185 A significant fraction of HMA is covered by glacier and semi-permanent snow owing to its extremely high elevation. Thus, it is important to distinguish seasonal vs. non-seasonal snow over land or glacier surfaces. In particular, the reanalysis method used in the development of the HMASR is best suited for seasonal snow characterization, because it relies on the 
https://doi.org/10.5194/tc-2021-139

Preprint. Discussion started: 17 May 2021

(c) Author(s) 2021. CC BY 4.0 License.

(c) (i)

signal between fSCA depletion time series and SWE via the LSM-SDC model. Hence, those pixels where there is not a full melt-out of snow are expected to be potentially erroneous. So, while estimates are generated at all pixels in the domain, the aim to focus on seasonal snow requires masking out semi-permanent snow and ice. Glacier inventories from the Global Land Ice Measurements from Space (GLIMS; Raup et al., 2007) and the Randolph Glacier Inventory (RGI; Pfeffer et al., 2014; RGI Consortium, 2017) have been employed in previous studies to exclude glaciers from snow modeling domains (e.g. Wrzesien et al, 2019, Smith and Bookhagen et al., 2018). Other studies such as Mudryk et al. (2015) and Mortimer et al. (2020) excluded glaciers based on estimates from the MERRA land fraction mask. Armstrong et al. (2019) applied the

195 MODIS Persistent Ice (MODICE; Painter et al., 2012) algorithm to derive a minimum snow and ice mask based on the MODSCAG product, and used it to distinguish seasonal snow from glaciers or persistent snow.

Herein a combination method was used to exclude the non-seasonal snow and ice pixels in HMASR, based on: 1) a glacier mask derived from GLIMS to identify glacierized pixels and 2) a persistent snow mask derived from the HMASR dataset itself. To be more specific on the second mask, pixels with a significant amount of persistent snow were identified, by comparing the annual minimum SWE at a particular pixel to its annual maximum SWE in each year. If the minimum SWE exceeds $10 \%$ of the maximum SWE for more than once out of the 18 years, this pixel is considered to be a persistent snow pixel to be masked out in the computation of seasonal snow estimates. The derived glacier and persistent snow masks are combined into a non-seasonal snow and ice mask, which is applied when presenting the spatiotemporal patterns of seasonal SWE and SWE volumes in the following section.

\section{Results and discussion}

The HMASR dataset is designed to provide a reliable and consistent SWE product that can be used for assessing the spatiotemporal distribution of seasonal SWE over the recent remote sensing record. To present an overall assessment of seasonal snowpack variability in the HMA region using the HMASR dataset, the results are organized as follows: 1) the spatial distribution of seasonal snowpack climatology, at annual and seasonal scales; 2) the temporal distribution of seasonal snowpack volume at basin and domain-wide scales; 3) the elevational distribution of seasonal snowpack storage at the basin scale.

\subsection{Spatial distribution of peak seasonal SWE climatology}

The spatial distribution of SWE is valuable in assessing the regional water storage and how it varies in time. Given the strong seasonal signature of snowpack processes over much of the domain, the pixel-wise peak SWE is a useful metric to quantify the distribution of the maximum amount of snow water mass held in the seasonal snowpack in a given water year. The climatology (18-year average) of pixel-wise peak SWE over the HMA region is depicted in Fig. 3, where Fig. 3a presents only the results for seasonal snow pixels (where non-seasonal snow and ice pixels have been masked out), and Fig. $3 \mathrm{~b}$ presents the results for all pixels for illustration (where significantly higher amounts of SWE shows up in non-seasonal 
https://doi.org/10.5194/tc-2021-139

Preprint. Discussion started: 17 May 2021

(c) Author(s) 2021. CC BY 4.0 License.

snow and ice mask pixels, corresponding to glaciers or permanent snow). The non-seasonal SWE values (Fig. 3b) are expected to be unreliable because the initial conditions for SWE at those locations at the beginning of the dataset are unknown and the lack of full melt-out makes the relationship between fSCA depletion and peak SWE much less direct.

(a)

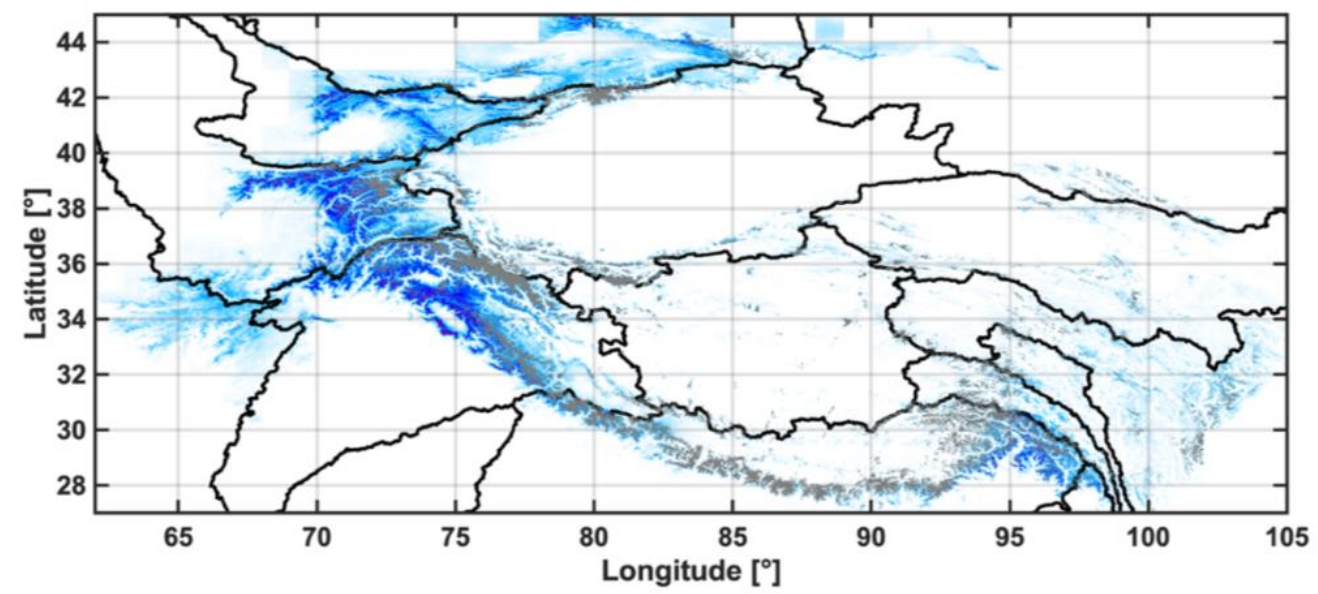

(b)

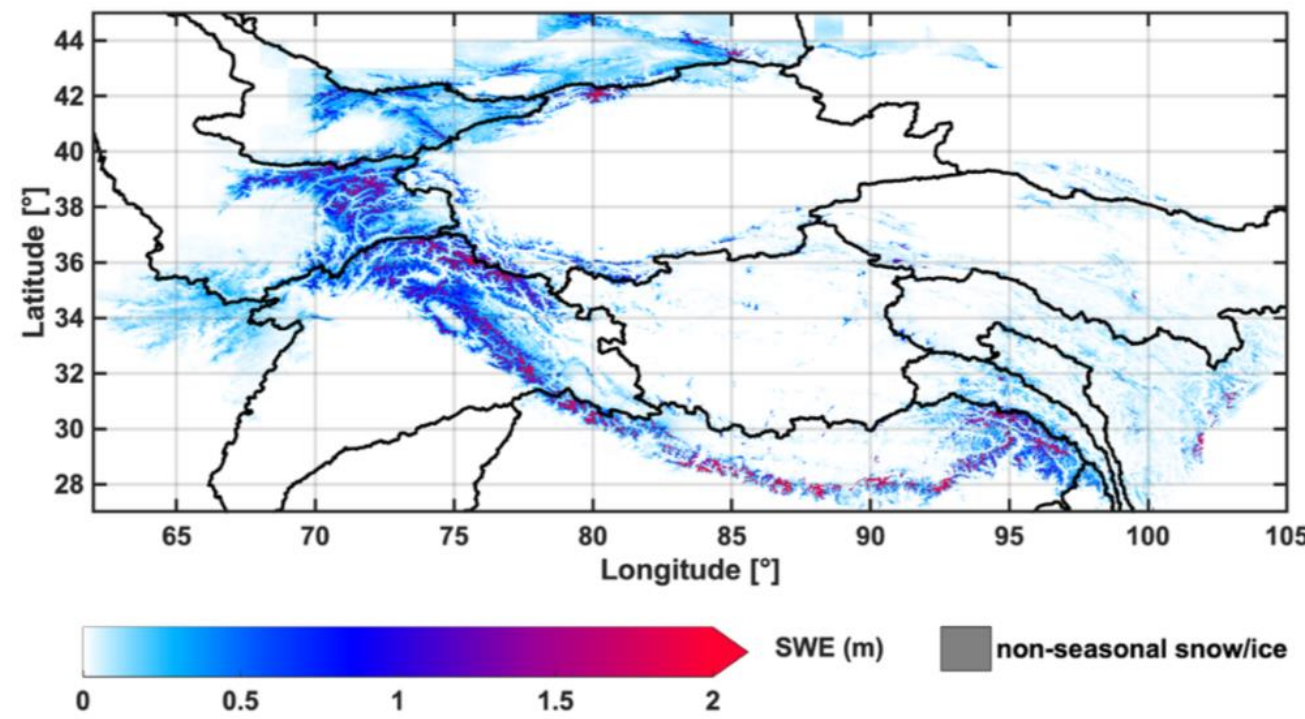

Figure 3 (a): Map of pixel-wise peak seasonal SWE climatology, with non-seasonal snow and ice pixels masked out (grey). (b): Map of pixel-wise peak seasonal SWE climatology, without masking of non-seasonal snow and ice pixels for reference.

225 In general, seasonal snow is most abundant in the NW region that is directly exposed to westerlies (Fig. 3a). Among the northwestern mountain ranges, the highest climatological peak SWE values are found in Pamir, Karakoram and the western Himalayas, with more than $1 \mathrm{~m}$ of peak SWE estimated. A significant amount of peak SWE is also estimated in Tien Shan and Hindu Kush, showing peak SWE values of $1 \mathrm{~m}$ or less in Tien Shan, and $0.5 \mathrm{~m}$ or less in Hindu Kush in general (Fig. 
https://doi.org/10.5194/tc-2021-139

Preprint. Discussion started: 17 May 2021

(c) Author(s) 2021. CC BY 4.0 License.

(c) (i)

3a). The non-seasonal snow and ice is most notable in Karakoram but also evident in a few locations over the Pamir, Tien

Shan and western Himalayas (Fig. 3b).

In contrast, seasonal snowpack is less abundant in the SE HMA (Fig. 3a), in part because it only receives much of its precipitation in summer from the Indian and East-Asia monsoons, while the winter westerlies have minimum impact. Shallow snowpack exists over the Hengduan Shan and Tanggula Shan, with low values of SWE estimated (less than $0.2 \mathrm{~m}$ ). For the Himalayas and Nyainqentanglha mountain ranges (Fig. 1), which exhibit extremely high elevation and receive significant summer precipitation from the monsoons, high values of SWE are estimated in some locations (Fig. 3b). However, those locations are masked out in the reanalysis through the non-seasonal snow and ice mask (Fig. 3a), because the fSCA observations are persistently high throughout the year (no observed melt-out), show irregular temporal patterns without a clear accumulation-depletion cycle (non-seasonal), or are obscured by clouds between June-Sept. (insufficient measurements), any of which can contribute to unreliable estimates of SWE.

240 The least abundant seasonal snowpack is estimated in the NE (Fig. 3a), where SWE is only notable over a few mountain ranges such as the Qilian Shan, Kunlun Shan and Eastern Tibetan mountains. Despite their high elevations, most of the NE areas are snow-free or only have shallow and intermittent snow, as a result of being further away from the primary atmospheric moisture sources.

Previous studies have also examined the spatiotemporal distribution in seasonal snowpack, regarding SCA (e.g. Pu et al.,

245 2007; Basang et al., 2017), snow depth and SWE (e.g. Terzago et al., 2014; Bian et al., 2019; Orsolini et al., 2019), and the overall finding is that most existing datasets present consistent spatial pattern at large scales (e.g. regional) but differ greatly in the magnitudes of SWE and snow depth, which implies large uncertainties in snow mass estimates over this data scarce region. Similarly, our dataset exhibits coherent spatial patterns compared to these previous efforts, yet the magnitudes of SWE still show significant uncertainty. A more comprehensive analysis of HMA SWE between multiple products will be addressed in an upcoming intercomparison paper using HMASR.

\subsection{Spatial distribution of peak SWE occurrence dates}

The timing of peak seasonal SWE occurrence is associated with climatological (e.g. precipitation) and topographic factors (e.g. elevation), and therefore shows significant heterogeneity over HMA. Figure 4 depicts the pixel-wise peak SWE day of water year (DOWY) climatology map. Highly intermittent snow pixels were excluded, as well as permanent snow and ice pixels via the non-seasonal snow and ice mask. Peak SWE generally occurs between DOWY 100 and DOWY 250 for seasonal snow. The median date of peak SWE is found on March 18th (DOWY 169), where the peak SWE occurs later than February 10th (DOWY 133) for over 90 percent of the domain, with peak SWE occurring later than May 5th (DOWY 217) for only 10 percent of the domain (Fig. 4). The peak SWE DOWY shows a bimodal distribution (Fig. 4, inset) with the earlier peak centered on DOWY 145 and the later peak centered on DOWY 192.

260 For those mountain ranges in the NW, the northern and western mountain slopes of Tien Shan, the western foothills of Pamir, the entire Hindu Kush, as well as the foothills of the western Himalayas, all have relatively early peak SWE 
https://doi.org/10.5194/tc-2021-139

Preprint. Discussion started: 17 May 2021

(C) Author(s) 2021. CC BY 4.0 License.

occurrences between February 10th and March 18th (Fig. 4). In contrast, the southern mountain slopes of Tien Shan, the majority of the Pamir, Karakoram, and western Himalaya, show a relatively late peak SWE occurrence between March 18th and May 5th (Fig. 4).

For those mountain ranges in the SE and NE, the peak SWE occurrence dates are more diverse (Fig. 4). In the SE, the central and eastern Himalayas, Nyainqentanglha, and Hengduan mountains generally have later peak SWE occurrences (between March 18th and May 5th), except in the southern foothills, where peak SWE tends to occur earlier (between February 10th and March 18th). In the NE, the Eastern Tibetan mountains show the earliest peak SWE occurrence dates (before February 10th), while the Qilian Shan and Kunlun Shan show the latest peak SWE occurrences (after May 5th).
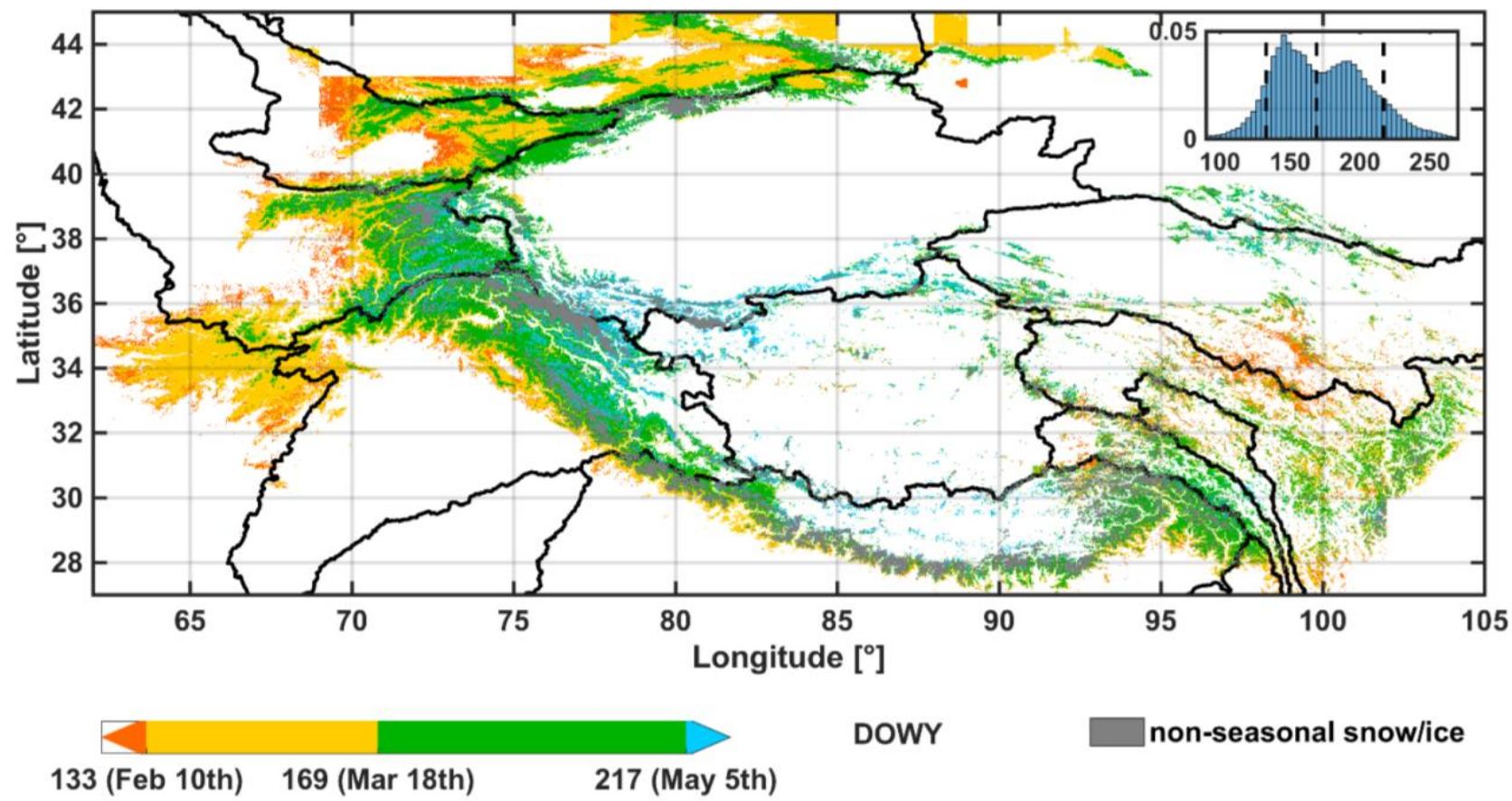

DOWY

non-seasonal snow/ice

Figure 4: Map of pixel-wise peak seasonal SWE DOWY climatology, with non-seasonal snow and ice pixels masked out (grey). The inset figure is the histogram of peak SWE DOWY. The three dates labeled in the colorbar (DOWY 133, DOWY 169 and DOWY 217) correspond to the 10th, 50th and 90th percentile in the DOWY distribution, and are marked with vertical dashed lines in the inset histogram.

\subsection{Spatial distribution of seasonal SWE climatology}

The seasonal patterns of SWE, averaged over SON (September, October, November), DJF (December, January, February), MAM (March, April, May), JJA (June, July, August), are shown in Fig. 5. As expected, higher SWE amounts are generally found in winter (DJF) and spring (MAM), while lower SWE amounts are found in summer (JJA) and fall (SON). Throughout the year, mountains in NW hold the maximum amount of SWE compared to other regions. In SON, the entire HMA region exhibits minimal SWE magnitudes $(0.1 \mathrm{~m}$ or below) and most regions are snow free (Fig. 5). During this 
https://doi.org/10.5194/tc-2021-139

Preprint. Discussion started: 17 May 2021

(c) Author(s) 2021. CC BY 4.0 License.

period, SWE starts accumulating in the Tien Shan, Pamir and western Himalayas that are directly facing the westerlies. SWE is also evident in Nyainqentanglha and Hengduan Shan that are associated with the summer monsoons. In DJF, both the overall magnitude and extent of SWE grow significantly, with mean SWE values up to $0.5 \mathrm{~m}$ found in Tien Shan, Pamir and western Himalayas (Fig. 5). The magnitude of SWE grows even larger in MAM, with up to $1 \mathrm{~m}$ SWE values estimated in the western HMA mountains, and up to $0.5 \mathrm{~m}$ SWE values estimated in Nyainqentanglha and the eastern Himalayas. Meanwhile, the extent of SWE shrinks significantly during MAM in the Hindu Kush and Tien Shan due to the weakened westerlies in spring. In JJA, both the magnitude and extent of SWE drop dramatically over most of the domain, with some exceptions of more persistent snowpack (with up to $0.3 \mathrm{~m}$ SWE) still evident in the Pamir, Karakoram and Nyainqentanglha, where snow melts out slower than the surrounding regions.
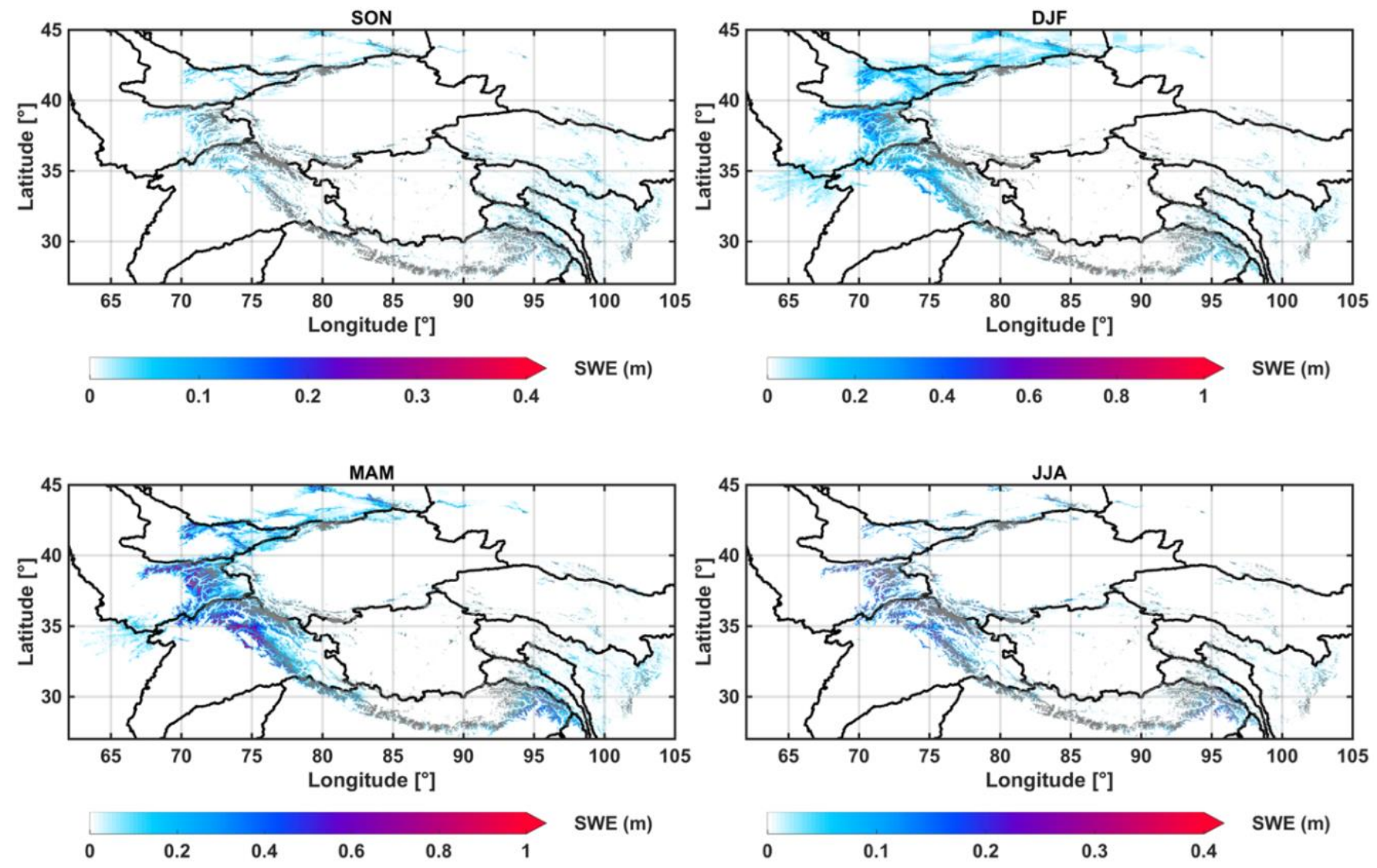

non-seasonal snow/ice

Figure 5: Map of mean seasonal SWE climatology in SON (September, October, November), DJF (December, January, February), MAM (March, April, May) and JJA (June, July, August), with non-seasonal snow and ice pixels masked out (grey). 
https://doi.org/10.5194/tc-2021-139

Preprint. Discussion started: 17 May 2021

(c) Author(s) 2021. CC BY 4.0 License.

\subsection{Temporal distribution of seasonal SWE volume}

The temporal variations in integrated seasonal SWE volume across the major river basins are quantified and examined from the 18-year average SWE seasonal cycle (i.e., daily time series shown in Fig. 6 and Fig. 7). Note again that the non-seasonal snow and ice mask has been applied when calculating the aggregated SWE volumes. The key statistics of annual peak SWE volumes are summarized for the entire HMA region and each basin in Table 1. Despite the significant literature on seasonal snowpack in this region, quantification of the regional scale SWE volume are more difficult to obtain, partly due to the large uncertainties in SWE estimation over this region.

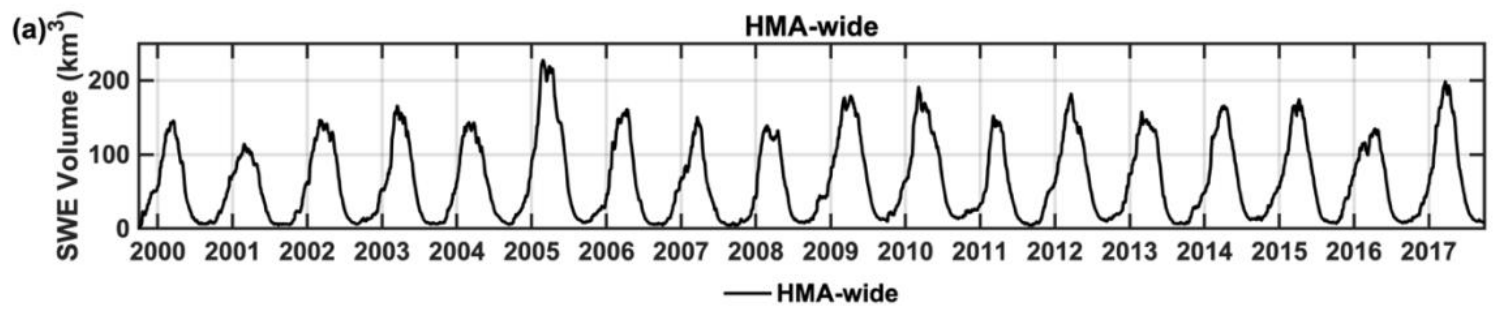

(b)

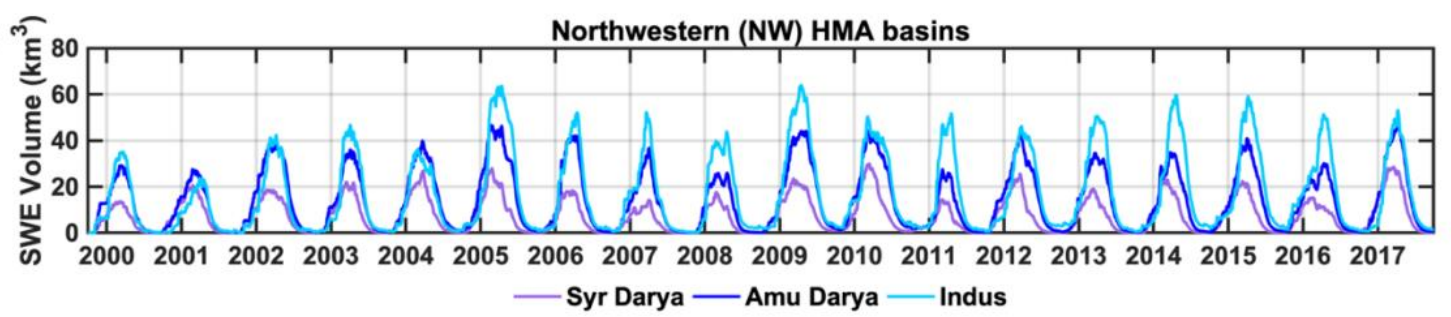

(c)

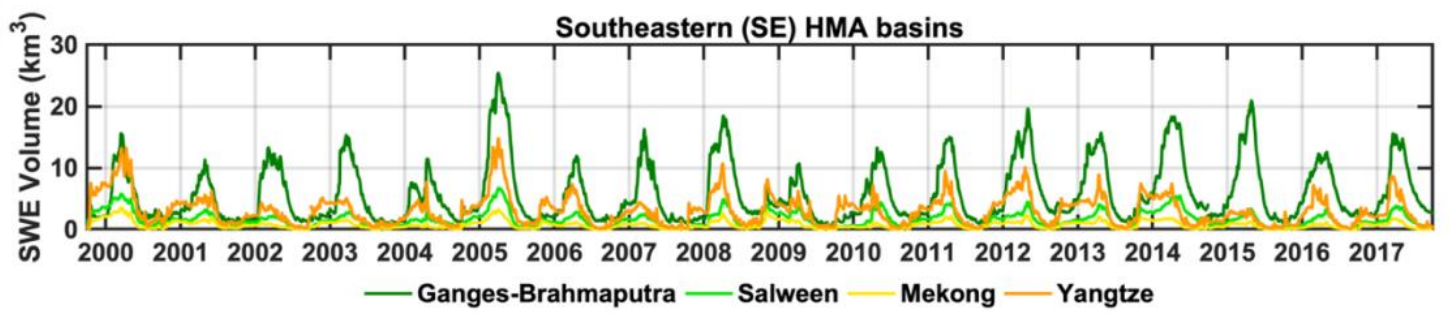

(d)

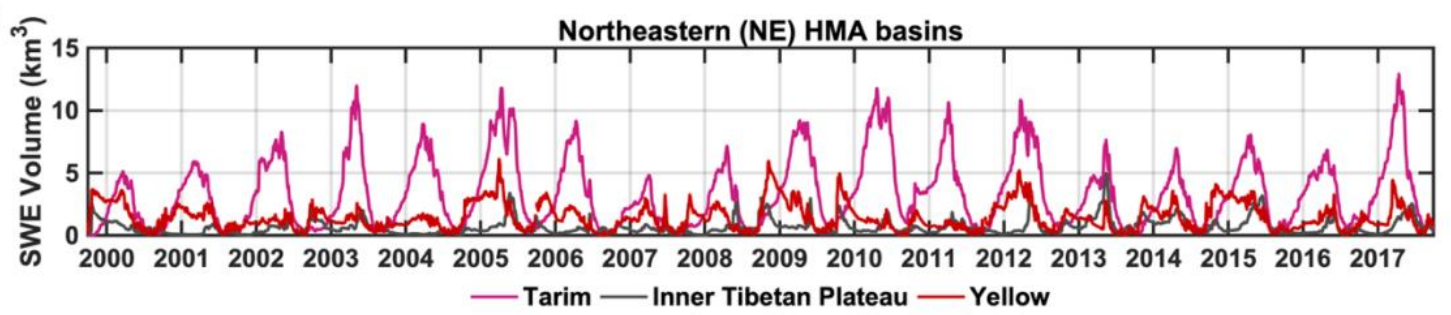

Figure 6: Daily time-series of seasonal SWE volume aggregated to (a) HMA-wide, (b) Northwestern (NW), (c) Southeastern (SE), and (d) Northeastern (NE) basin totals. 
https://doi.org/10.5194/tc-2021-139

Preprint. Discussion started: 17 May 2021

(C) Author(s) 2021. CC BY 4.0 License.

(c) (i)

(a)

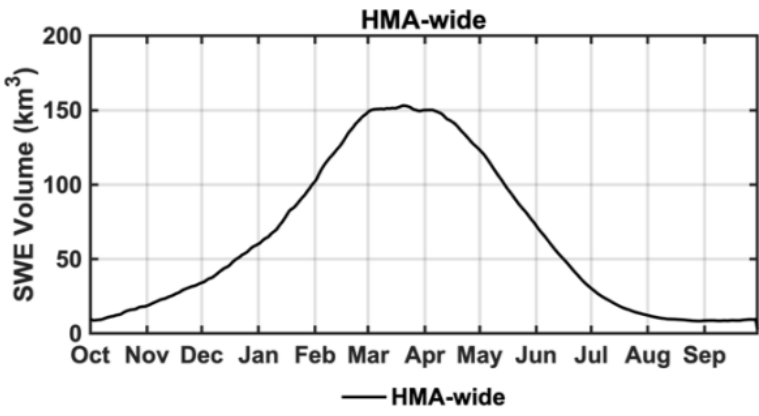

(c)

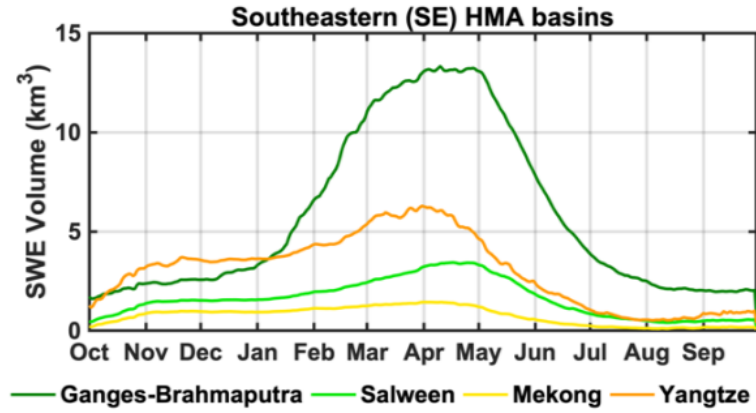

(b)

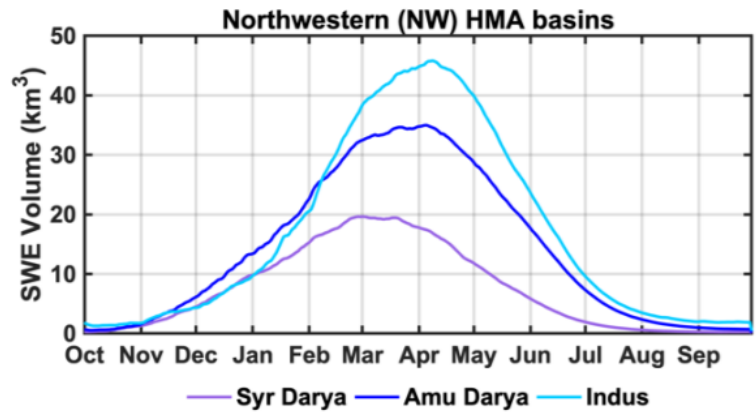

(d)

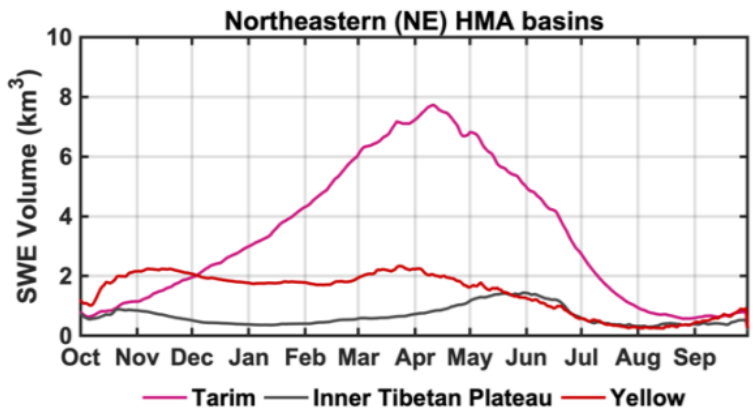

305 Figure 7: Climatological (18-year average) daily time series of seasonal SWE volumes, aggregated to a) HMA-wide, (b) Northwestern (NW), (c) Southeastern (SE), and (d) Northeastern (NE) basin totals.

Over the record examined, the HMA-wide annual peak SWE volume (Fig. 6a and Fig. 7a) is found to be largest in WY2005 with a value of $227.12 \mathrm{~km}^{3}$, smallest in WY2001 with a value of $114.10 \mathrm{~km}^{3}$, and an 18 -year climatological mean value of $162.58 \mathrm{~km}^{3}$. The climatological peak SWE volume was further assessed in each subregion, and compared against that over the entire HMA (Table 1; Fig. 7). The results show the highest peak SWE volume occurs in NW basins $\left(107.42 \mathrm{~km}^{3}, \sim 66 \%\right.$ of domain-wide total), followed by SE basins $\left(29.49 \mathrm{~km}^{3}, \sim 18 \%\right)$, and NE basins $\left(14.78 \mathrm{~km}^{3}\right.$, $\left.~ 9 \%\right)$, which is coherent with the spatial pattern shown in Fig. 3a. Note that around $\sim 7 \%$ of HMA-wide SWE volume falls in the regions outside of the watersheds examined (mainly in the northmost regions shown in Fig. 1), which is why these basin-wide quantities do not sum up to $100 \%$ of the HMA-wide totals.

315 For the NW basins, the maximum amount of SWE volume is found in the Indus basin, followed by Amu Darya and Syr Darya (Fig. 6b and Fig. 7b). Meanwhile, the peak SWE volume is found to occur earlier and disappear faster in the Syr Darya basin, followed by Amu Darya and Indus, with later melt-out corresponding to larger peak SWE volume magnitudes. When examining the peak SWE volumes in each basin (Fig. $6 \mathrm{~b}$ and Fig. 7b), the Indus was found to have the highest value of $63.97 \mathrm{~km}^{3}$ in WY2009, and an average of $48.95 \mathrm{~km}^{3}$ across the 18 years; Amu Darya shows the highest peak SWE volume of $48.31 \mathrm{~km}^{3}$ in WY2017, and an average peak SWE volume of $37.31 \mathrm{~km}^{3}$ across all 18 years; Syr Darya shows a peak SWE volume of $21.16 \mathrm{~km}^{3}$ on average (Table 1).

For the SE basins, higher SWE volumes are found in Ganges-Brahmaputra, followed by Yangtze, Salween and Mekong (Fig. 6c and Fig. 7c). As shown in Table 1, Ganges-Brahmaputra has an average peak SWE volume of $15.59 \mathrm{~km}^{3}$, with a 
https://doi.org/10.5194/tc-2021-139

Preprint. Discussion started: 17 May 2021

(c) Author(s) 2021. CC BY 4.0 License.

(c) (i)

carry-over SWE volume of around $2 \mathrm{~km}^{3}$ at the end of the WY (Fig. 7c); the Yangtze basin has an average peak SWE

volume of $8.02 \mathrm{~km}^{3}$, with a maximum of $14.79 \mathrm{~km}^{3}$ in WY2005; Salween and Mekong have much lower SWE volumes that are generally less than $5 \mathrm{~km}^{3}$, partly due to their small basin sizes (Fig. 1).

For the NE basins over HMA, the overall magnitude of SWE volumes is smallest (Fig. 6d and Fig. 7d), with an average peak SWE volume of $8.78 \mathrm{~km}^{3}$ in Tarim, $3.65 \mathrm{~km}^{3}$ in Yellow, and $2.35 \mathrm{~km}^{3}$ in Inner Tibetan Plateau respectively (Table 1). These basins all have relatively large areas, but are mostly snow-free or covered by shallow snow as depicted in Fig. $3 \mathrm{a}$.

Table 1: Summary statistics for HMA-wide and basin-wide annual peak SWE volume assessed from the 18-year HMASR.

\begin{tabular}{|c|c|c|c|c|c|c|c|c|}
\hline \multirow[b]{2}{*}{ Region } & \multirow[b]{2}{*}{ Basin name } & \multicolumn{7}{|c|}{ Peak SWE volume } \\
\hline & & $\begin{array}{l}\operatorname{Max} \\
\left(\mathrm{km}^{3}\right)\end{array}$ & $\begin{array}{c}\text { Min } \\
\left(\mathrm{km}^{3}\right)\end{array}$ & $\begin{array}{l}\text { Mean } \\
\left(\mathrm{km}^{3}\right)\end{array}$ & $\begin{array}{c}\text { Standard } \\
\text { deviation } \\
\left(\mathrm{km}^{3}\right)\end{array}$ & $\begin{array}{l}\text { Max } \\
\text { year }\end{array}$ & $\begin{array}{l}\text { Min } \\
\text { year }\end{array}$ & $\begin{array}{c}\text { Total of } \\
\text { subregional } \\
\text { mean }\left(\mathrm{km}^{3}\right)\end{array}$ \\
\hline HMA-wide & HMA-wide & 227.12 & 114.10 & 162.57 & 26.53 & 2005 & 2001 & $\begin{array}{c}162.57 \\
(100 \%)\end{array}$ \\
\hline \multirow{3}{*}{$\begin{array}{l}\text { Northwestern } \\
(\mathrm{NW}) \text { basins }\end{array}$} & Syr Darya & 29.88 & 13.61 & 21.16 & 5.19 & 2010 & 2000 & \multirow{3}{*}{$\begin{array}{l}107.42 \\
(66 \%)\end{array}$} \\
\hline & Amu Darya & 48.31 & 25.92 & 37.31 & 7.10 & 2017 & 2008 & \\
\hline & Indus & 63.97 & 23.71 & 48.95 & 10.27 & 2009 & 2001 & \\
\hline \multirow{4}{*}{$\begin{array}{l}\text { Southeastern } \\
\text { (SE) basins }\end{array}$} & Ganges-Brahmaputra & 25.40 & 10.69 & 15.59 & 3.84 & 2005 & 2009 & \multirow{4}{*}{$\begin{array}{c}29.49 \\
(18 \%)\end{array}$} \\
\hline & Salween & 6.71 & 2.21 & 3.97 & 1.23 & 2005 & 2002 & \\
\hline & Mekong & 3.56 & 1.02 & 1.92 & 0.77 & 2000 & 2004 & \\
\hline & Yangtze & 14.79 & 3.32 & 8.02 & 2.97 & 2005 & 2015 & \\
\hline \multirow{3}{*}{$\begin{array}{l}\text { Northeastern } \\
\text { (NE) basins }\end{array}$} & Tarim & 12.92 & 4.81 & 8.78 & 2.45 & 2017 & 2007 & \multirow{3}{*}{$\begin{array}{l}14.78 \\
(9 \%)\end{array}$} \\
\hline & Inner Tibetan Plateau & 4.98 & 0.57 & 2.35 & 0.99 & 2013 & 2004 & \\
\hline & Yellow & 6.10 & 1.76 & 3.65 & 1.25 & 2005 & 2004 & \\
\hline
\end{tabular}

\subsection{Elevational distribution of basin-wide peak SWE volume}

Finally, the domain-wide and basin-wide peak seasonal SWE and SWE volume climatology distribution vs. elevation was 335 assessed (Fig. 8), obtained at the DOWYs when domain-wide or basin-wide SWE volumes reach their annual maximum (averaged over 18 years). The HMA-wide domain (Fig. 8a) and each basin (Fig. 8b, Fig. 8c and Fig. 8d) were divided into 5percentile elevation bins, so that the aggregated SWE volumes are calculated over comparable areas, following the method 
https://doi.org/10.5194/tc-2021-139

Preprint. Discussion started: 17 May 2021

(c) Author(s) 2021. CC BY 4.0 License.

in Smith and Bookhagen (2018). The non-seasonal snow and ice pixels were removed when calculating peak SWE volume, and its fractional areal coverage within a given elevation band, is computed to assess the relative elevational contributions to total seasonal SWE volume (Fig. 8). Similar work has been done in Smith and Bookhagen (2018) that assessed the SWE trends in different elevation bands over HMA-wide and basin-wide scales, while here we focus more on a quantitative assessment in the SWE volume distribution itself against elevation.
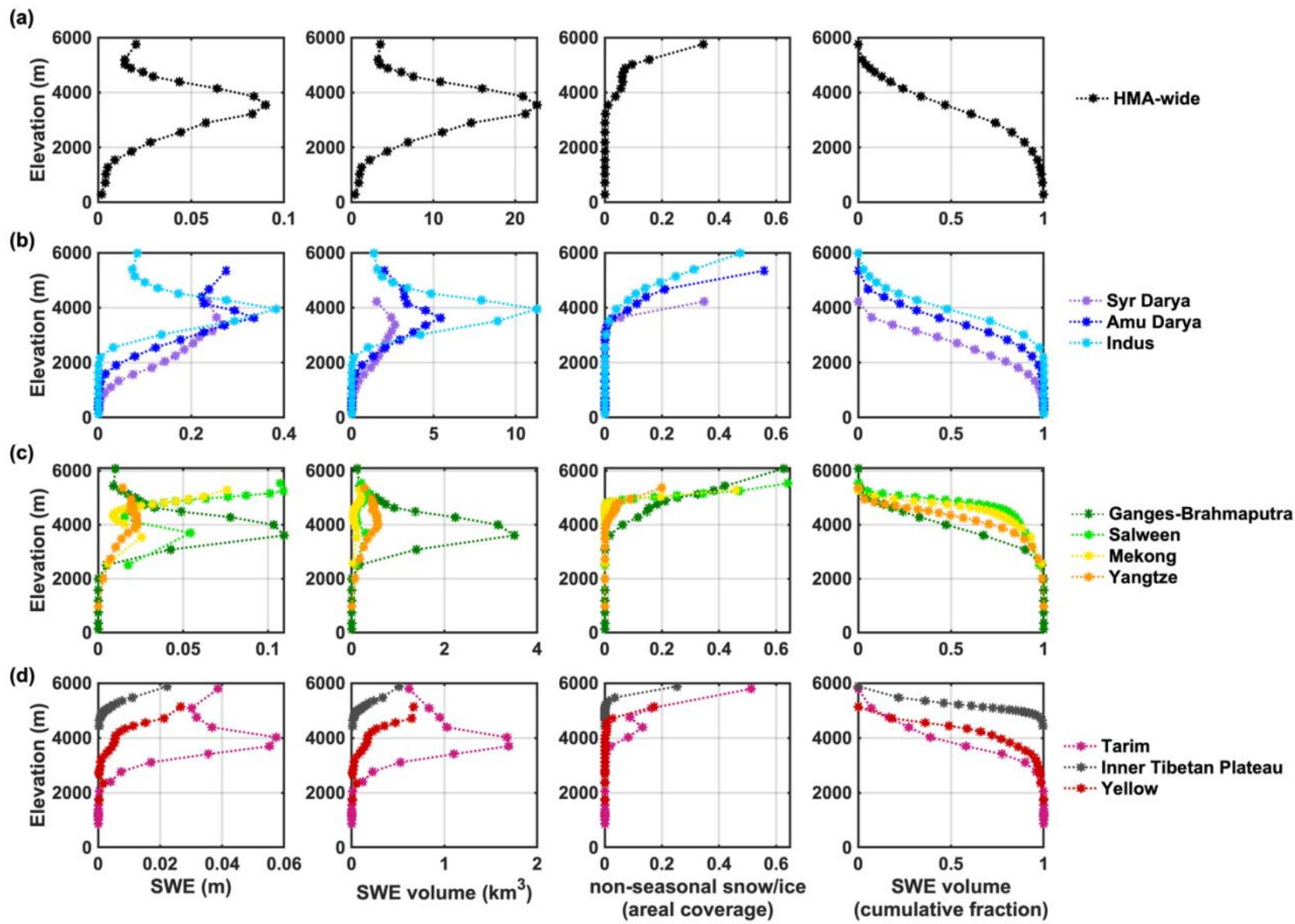

Figure 8: (a) HMA-wide, (b) Northwestern (NW), (c) Southeastern (SE), (d) Northeastern (NE) basin-wide peak seasonal SWE

climatology (first column), SWE volume climatology (second column), fractional areal coverage of non-seasonal snow and ice within each elevation band (third column), and cumulative fraction of SWE volume above the specified elevation (fourth column), where the elevation is discretized into $5 \%$ percentile bins.

When examining the full HMA domain, the seasonal SWE volume was found to be most abundant at mid elevations (3000 $4000 \mathrm{~m}$ ), with peak SWE values occurring at elevations around $3500 \mathrm{~m}$ (Fig. 8a). Meanwhile, the presence of non-seasonal snow and ice becomes evident at elevations above $3500 \mathrm{~m}$, and it increases dramatically above $5000 \mathrm{~m}$ with a value up to $35 \%$ (Fig. 8a). When assessing the cumulative fraction of SWE volume as a function of elevation, it was found that over 
https://doi.org/10.5194/tc-2021-139

Preprint. Discussion started: 17 May 2021

(c) Author(s) 2021. CC BY 4.0 License.

\section{(c) (i)}

$50 \%$ of seasonal SWE volume is stored at elevations above $3500 \mathrm{~m}$, and less than $10 \%$ of seasonal SWE volume is stored at elevations below $2000 \mathrm{~m}$ (Fig. 8a).

Within all NW basins (Syr Darya, Amu Darya and Indus; Fig. 8b) as well as Tarim in NE (Fig. 8d), and Ganges-

Brahmaputra and Yangtze in SE (Fig. 8c), both the SWE depth and SWE volumes increase with elevation (below 4000 m) and then decline with elevation (above $\sim 4000 \mathrm{~m}$ ). This corresponds to an increase in non-seasonal snow and ice coverage (up to $60 \%$ ) above $4000 \mathrm{~m}$, which may be primarily responsible for the reduction in seasonal SWE volumes seen at high elevations. Other basins in SE (Salween, Mekong; Fig. 8c) and NE (Yellow, Inner Tibetan Plateau; Fig. 8d) generally show monotonically increasing SWE and SWE volumes against elevation. This is partly due to a much lower non-seasonal snow and ice coverage (mostly under 25\%) at high elevations in those basins. For the cumulative fraction of SWE volumes above a specified elevation, the median values are found within 3000 to $4000 \mathrm{~m}$ in NW basins (Fig. 8b). Meanwhile, the median values are found at higher elevations for SE and NE (between 4000 - $5200 \mathrm{~m}$ ) basins (Fig. 8c and Fig. 8d).

\section{Conclusions}

A first-order spatiotemporal analysis of seasonal SWE over the HMA region is presented in this paper, using a new 18-year

365 snow reanalysis dataset (HMASR; Liu et al., 2021). This HMASR dataset is derived based on a previously developed snow reanalysis scheme (Margulis et al., 2019) that jointly assimilates fSCA observations from both Landsat and MODSCAG products, which has daily outputs of SWE and other snow variables, with a spatial resolution of 16 arc-second ( 500 m), over the joint period of Landsat and MODIS from WYs 2000 to 2017.

Several scientific questions were addressed in this work using the new HMASR dataset, such as how seasonal SWE and snow storage distribute with space, time and elevation. In terms of the spatial distribution, seasonal snow is most abundant in the NW, with over $1 \mathrm{~m}$ of peak SWE observed over the mountain ranges. Seasonal snow is also significant in the SE, where both relatively deep snowpacks (with peak SWE values up to $1 \mathrm{~m}$ or above) and shallow snowpacks (with peak SWE up to $0.2 \mathrm{~m}$ ) are found. Seasonal snow is less abundant in the NE where most areas are snow free, or only covered by shallow snowpacks (with peak SWE values below $0.2 \mathrm{~m}$ ). The domain-wide median date of peak SWE is estimated to be March 18th with significant heterogeneity across this region, linked with climatological drivers and topography.

When aggregating the total SWE volumes across the full HMA domain and its basins, the climatological peak seasonal SWE volume was found to be $163 \mathrm{~km}^{3}$, with NW basins accounting for around $66 \%$ of that volume, followed by SE ( 18\%) and NE ( 9\%) basins. This peak seasonal SWE volume showed a maximum value in WY2005 $\left(227 \mathrm{~km}^{3}\right)$ and a minimum value in WY2001 $\left(114 \mathrm{~km}^{3}\right)$ when assessed over the entire HMA region in the study period. The elevational distribution of seasonal peak SWE volume shows that SWE volume is most abundant at mid-elevations (3000 - $4000 \mathrm{~m}$ ), with over 50\% of the seasonal SWE volume stored at elevations above $3500 \mathrm{~m}$, when assessed over the entire HMA region.

This HMASR dataset is presented to augment the spatiotemporal gaps in previous SWE datasets and provide better characterization of spatiotemporal patterns in seasonal snowpack over the HMA region, especially over the mountainous 
https://doi.org/10.5194/tc-2021-139

Preprint. Discussion started: 17 May 2021

(c) Author(s) 2021. CC BY 4.0 License.

(c) (i)

areas with complex terrain where existing products tend to underestimate SWE and present large uncertainties (Wrzesien et al., 2019; Kim et al., 2021). It should prove useful in providing more insight into the role of seasonal snowpack in the regional hydrological cycle, as a verification dataset for atmospheric and other models, and in other applications where a space-time continuous snow dataset constrained by remote sensing data is needed.

A key limitation in the dataset is that, it is most effective in estimating seasonal snowpack, as the method requires a seasonal cycle of FSCA with a clear depletion signal. It is therefore not designed to provide estimates of SWE associated with glaciers or semi-permanent snow, and is generally expected to be less accurate in areas of intermittent and very shallow snowpack. In addition, limited fSCA observations due to cloud contamination during monsoon seasons may result in higher uncertainty in SWE estimation over affected sub-regions like the Himalayas. Other remote-sensing approaches (e.g., active microwave measurements) that could penetrate clouds may potentially aid in reducing the uncertainties for SWE estimation over those areas. More research can be done to address such issues and improve the accuracy of SWE estimates for those regions in the future.

Data availability. The HMASR dataset used in this paper, is publicly available on National Snow and Ice Data Center (NSIDC) HiMAT data repository, entitled: 'High-Mountain Asia UCLA Daily Snow Reanalysis, Version 1'. It can be accessed through https://nsidc.org/data/HMA_SR_D/ or https://doi.org/10.5067/HNAUGJQXSCVU (Liu et al., 2021). The dataset is provided as NetCDF files for each $1^{\circ} \mathrm{x} 1^{\circ}$ tile shown in Fig. 1, available at 16 arc-second $(\sim 500 \mathrm{~m})$ and daily resolution from WYs 2000 to 2017. Posterior estimates of other key snowpack properties (i.e. in addition to SWE) not focused on herein (e.g. snow depth, fSCA, snowmelt, sublimation, snow albedo, etc.) along with posterior forcing variables are included in this dataset. Data quality information, containing a classification mask and the non-seasonal snow/ice mask, can be found in the dataset as well.

Author contribution. YL led the production of the dataset and led the analysis in the manuscript. YF contributed to the 405 production of the dataset and contributed to the analysis in the manuscript. SM supervised the project and provided guidance. All authors contributed to writing the manuscript.

Competing interests. The authors declare that they have no conflict of interest.

Acknowledgements. We would like to thank those responsible for the creation of the datasets used in this study as well as members of the NASA High-Mountain Asia Team (HiMAT) who helped shape the overall direction of the work. G. Cortes 410 is acknowledged for pre-processing some of the input data used to develop the HMASR dataset. This research was funded by the NASA High-Mountain Asia Program Grant \#NNX16AQ63G with additional support provided by NSF Grant \#1641960. 
https://doi.org/10.5194/tc-2021-139

Preprint. Discussion started: 17 May 2021

(c) Author(s) 2021. CC BY 4.0 License.

(c) (i)

\section{References}

Ahmad, J. A., Forman, B. A. and Kwon, Y.: Analyzing Machine Learning Predictions of Passive Microwave Brightness

Temperature Spectral Difference Over Snow-Covered Terrain in High Mountain Asia, Front. Earth Sci., 7, 249, doi:10.3389/feart.2019.00212, 2019.

Armstrong, R. L., Rittger, K., Brodzik, M. J., Racoviteanu, A., Barrett, A. P., Khalsa, S.-J. S., Raup, B., Hill, A. F., Khan, A. L., Wilson, A. M., Kayastha, R. B., Fetterer, F. and Armstrong, B.: Runoff from glacier ice and seasonal snow in High Asia: separating melt water sources in river flow, Reg Environ Change, 19(5), 1249-1261, 2019.

Barnett, T. P., Adam, J. C. and Lettenmaier, D. P.: Potential impacts of a warming climate on water availability in snowdominated regions, Nature, 438(7066), 303-309, 2005.

Basang, D., Barthel, K., and Olseth, J. A.: Satellite and Ground Observations of Snow Cover in Tibet during 2001-2015, Remote Sensing, 9, 1201, https://doi.org/10.3390/rs9111201, 2017.

Bian, Q., Xu, Z., Zhao, L., Zhang, Y.-F., Zheng, H., Shi, C., Zhang, S., Xie, C. and Yang, Z.-L.: Evaluation and Intercomparison of Multiple Snow Water Equivalent Products over the Tibetan Plateau, Journal of Hydrometeorology, 20(10), 2043-2055, doi:10.1175/JHM-D-19-0011.1, 2019.

Bolch, T., Kulkarni, A., Kaab, A., Huggel, C., Paul, F., Cogley, J. G., Frey, H., Kargel, J. S., Fujita, K., Scheel, M., Bajracharya, S. and Stoffel, M.: The State and Fate of Himalayan Glaciers, Science, 336(6079), 310, 2012.

Bolch, T., Shea, J. M., Liu, S., Azam, F. M., Gao, Y., Gruber, S., Immerzeel, W. W., Kulkarni, A., Li, H., Tahir, A. A., Zhang, G. and Zhang, Y.: Status and Change of the Cryosphere in the Extended Hindu Kush Himalaya Region, in The Hindu

Kush Himalaya Assessment: Mountains, Climate Change, Sustainability and People, edited by P. Wester, A. Mishra, A. Mukherji, and A. B. Shrestha, pp. 209-255, Springer International Publishing, Cham. 2019.

Bookhagen, B. and Burbank, D. W.: Toward a complete Himalayan hydrological budget: Spatiotemporal distribution of snowmelt and rainfall and their impact on river discharge, J. Geophys. Res., 115(F3), 39, doi:10.1029/2009JF001426, 2010.

Bormann, K. J., Brown, R. D., Derksen, C. and Painter, T. H.: Estimating snow-cover trends from space, Nature Clim

Change, 8(11), 924-928, 2018.

Chang, A. T. C., Foster, J. L. and Hall, D. K.: Nimbus-7 SMMR Derived Global Snow Cover Parameters, Annals of Glaciology, 9, 39-44, 1987.

Che, T., Li, X., Jin, R., Armstrong, R. and Zhang, T.: Snow depth derived from passive microwave remote-sensing data in China, Annals of Glaciology, 49, 145-154, 2008.

440 Cortés, G., Girotto, M. and Margulis, S. A.: Analysis of sub-pixel snow and ice extent over the extratropical Andes using spectral unmixing of historical Landsat imagery, Remote Sensing of Environment, 141, 64-78, 2014.

Cortés, G. and Margulis, S.: Impacts of El Niño and La Niña on interannual snow accumulation in the Andes: Results from a high-resolution 31 year reanalysis, Geophys. Res. Lett., 44(13), 6859-6867, doi:10.1002/2017GL073826, 2017. 
https://doi.org/10.5194/tc-2021-139

Preprint. Discussion started: 17 May 2021

(c) Author(s) 2021. CC BY 4.0 License.

(c) (i)

Dahe, Q., Shiyin, L. and Peiji, L.: Snow Cover Distribution, Variability, and Response to Climate Change in Western China,

J. Climate, 19(9), 1820-1833, doi:10.1175/JCLI3694.1, 2006.

Dai, L., Che, T., Ding, Y. and Hao, X.: Evaluation of snow cover and snow depth on the Qinghai--Tibetan Plateau derived from passive microwave remote sensing, The Cryosphere, 11(4), 1933-1948, doi:10.5194/tc-11-1933-2017, 2017.

Dee, D. P., Uppala, S. M., Simmons, A. J., Berrisford, P., Poli, P., Kobayashi, S., Andrae, U., Balmaseda, M. A., Balsamo, G., Bauer, P., Bechtold, P., Beljaars, A. C. M., van de Berg, L., Bidlot, J., Bormann, N., Delsol, C., Dragani, R., Fuentes, M.,

Geer, A. J., Haimberger, L., Healy, S. B., Hersbach, H., Hólm, E. V., Isaksen, L., Kållberg, P., Köhler, M., Matricardi, M., McNally, A. P., Monge-Sanz, B. M., Morcrette, J. J., Park, B. K., Peubey, C., de Rosnay, P., Tavolato, C., Thépaut, J. N. and Vitart, F.: The ERA-Interim reanalysis: configuration and performance of the data assimilation system, Q.J.R. Meteorol. Soc., 137(656), 553-597, doi:10.1002/qj.828, 2011.

Dozier, J.: Spectral signature of alpine snow cover from the landsat thematic mapper, Remote Sensing of Environment, 28, 9-22, doi:https://doi.org/10.1016/0034-4257(89)90101-6, 1989.

Dozier, J., Bair, E. H. and Davis, R. E.: Estimating the spatial distribution of snow water equivalent in the world's mountains, WIREs Water, 3(3), 461-474, doi:10.1002/wat2.1140, 2016.

Durand, M., Molotch, N. P. and Margulis, S. A.: A Bayesian approach to snow water equivalent reconstruction, J. Geophys. Res., 113(D20), 872, doi:10.1029/2008JD009894, 2008.

Gelaro, R., McCarty, W., Suárez, M. J., Todling, R., Molod, A., Takacs, L., Randles, C. A., Darmenov, A., Bosilovich, M. G., Reichle, R., Wargan, K., Coy, L., Cullather, R., Draper, C., Akella, S., Buchard, V., Conaty, A., da Silva, A. M., Gu, W., Kim, G.-K., Koster, R., Lucchesi, R., Merkova, D., Nielsen, J. E., Partyka, G., Pawson, S., Putman, W., Rienecker, M., Schubert, S. D., Sienkiewicz, M. and Zhao, B.: The Modern-Era Retrospective Analysis for Research and Applications, Version 2 (MERRA-2), J. Climate, 30(14), 5419-5454, 2017.

465 Girotto, M., Margulis, S. A. and Durand, M.: Probabilistic SWE reanalysis as a generalization of deterministic SWE reconstruction techniques, Hydrol. Process., 28(12), 3875-3895, doi:10.1002/hyp.9887, 2014.

Hall, D. K., Riggs, G. A., Salomonson, V. V., DiGirolamo, N. E. and Bayr, K. J.: MODIS snow-cover products, Remote Sensing of Environment, 83(1), 181-194, 2002.

Hansen, M. C., Defries, R. S., Townshend, J. R. G. and Sohlberg, R.: Global land cover classification at $1 \mathrm{~km}$ spatial 470 resolution using a classification tree approach, International Journal of Remote Sensing, 21(6-7), 1331-1364, doi:10.1080/014311600210209, 2000.

Hersbach, H., Bell, B., Berrisford, P., Hirahara, S., Horányi, A., Muñoz Sabater, J., Nicolas, J., Peubey, C., Radu, R., Schepers, D., Simmons, A., Soci, C., Abdalla, S., Abellan, X., Balsamo, G., Bechtold, P., Biavati, G., Bidlot, J., Bonavita, M., Chiara, G., Dahlgren, P., Dee, D., Diamantakis, M., Dragani, R., Flemming, J., Forbes, R., Fuentes, M., Geer, A., 475 Haimberger, L., Healy, S., Hogan, R. J., Hólm, E., Janisková, M., Keeley, S., Laloyaux, P., Lopez, P., Lupu, C., Radnoti, G., Rosnay, P., Rozum, I., Vamborg, F., Villaume, S. and Thépaut, J. N.: The ERA5 global reanalysis, Q.J.R. Meteorol. Soc., 146(730), 1999-2049, doi:10.1002/qj.3803, 2020. 
https://doi.org/10.5194/tc-2021-139

Preprint. Discussion started: 17 May 2021

(c) Author(s) 2021. CC BY 4.0 License.

Immerzeel, W. W., Droogers, P., de Jong, S. M. and Bierkens, M. F. P.: Large-scale monitoring of snow cover and runoff simulation in Himalayan river basins using remote sensing, Remote Sensing of Environment, 113(1), 40-49, 2009.

Immerzeel, W. W., van Beek, L. P. H. and Bierkens, M. F. P.: Climate Change Will Affect the Asian Water Towers, Science, 328(5984), 1382, 2010.

Immerzeel, W. W. and Bierkens, M. F. P.: Asia's water balance, Nature Geoscience, 5(12), 841-842, 2012.

Immerzeel, W. W., Lutz, A. F., Andrade, M., Bahl, A., Biemans, H., Bolch, T., Hyde, S., Brumby, S., Davies, B. J., Elmore, A. C., Emmer, A., Feng, M., Fernández, A., Haritashya, U., Kargel, J. S., Koppes, M., Kraaijenbrink, P. D. A., Kulkarni, A.

V., Mayewski, P. A., Nepal, S., Pacheco, P., Painter, T. H., Pellicciotti, F., Rajaram, H., Rupper, S., Sinisalo, A., Shrestha, A. B., Viviroli, D., Wada, Y., Xiao, C., Yao, T. and Baillie, J. E. M.: Importance and vulnerability of the world's water towers, Nature, 577(7790), 364-369, 2020.

Kääb, A., Berthier, E., Nuth, C., Gardelle, J. and Arnaud, Y.: Contrasting patterns of early twenty-first-century glacier mass change in the Himalayas, Nature, 488(7412), 495-498, 2012.

490 Kim, R. S., Kumar, S., Vuyovich, C., Houser, P., Lundquist, J., Mudryk, L., Durand, M., Barros, A., Kim, E. J., Forman, B. A., Gutmann, E. D., Wrzesien, M. L., Garnaud, C., Sandells, M., Marshall, H. P., Cristea, N., Pflug, J. M., Johnston, J., Cao, Y., Mocko, D. and Wang, S.: Snow Ensemble Uncertainty Project (SEUP): quantification of snow water equivalent uncertainty across North America via ensemble land surface modeling, The Cryosphere, 15(2), 771-791, doi:10.5194/tc-15771-2021, 2021.

Kirkham, J. D., Koch, I., Saloranta, T. M., Litt, M., Stigter, E. E., Møen, K., Thapa, A., Melvold, K. and Immerzeel, W. W.: Near Real-Time Measurement of Snow Water Equivalent in the Nepal Himalayas, Front. Earth Sci., 7, 677, doi:10.3389/feart.2019.00177, 2019.

KOBAYASHI, S., OTA, Y., HARADA, Y., EBITA, A., MORIYA, M., ONODA, H., ONOGI, K., KAMAHORI, H., KOBAYASHI, C., ENDO, H., MIYAOKA, K. and TAKAHASHI, K.: The JRA-55 Reanalysis: General Specifications and

Basic Characteristics TI , Journal of the Meteorological Society of Japan. Ser. II, 93(1), 5-48, 2015.

Largeron, C., Dumont, M., Morin, S., Boone, A., Lafaysse, M., Metref, S., Cosme, E., Jonas, T., Winstral, A. and Margulis, S. A.: Toward Snow Cover Estimation in Mountainous Areas Using Modern Data Assimilation Methods: A Review, Front. Earth Sci., 8, 325, doi:10.3389/feart.2020.00325, 2020.

Lehner, B., Verdin, K. and Jarvis, A.: New Global Hydrography Derived From Spaceborne Elevation Data, Eos Trans. AGU, 89(10), 93-94, doi:10.1029/2008EO100001, 2008.

Lettenmaier, D. P., Alsdorf, D., Dozier, J., Huffman, G. J., Pan, M. and Wood, E. F.: Inroads of remote sensing into hydrologic science during the WRR era, Water Resour. Res., 51(9), 7309-7342, doi:10.1002/2015WR017616, 2015.

Lievens, H., Demuzere, M., Marshall, H.-P., Reichle, R. H., Brucker, L., Brangers, I., de Rosnay, P., Dumont, M., Girotto, M., Immerzeel, W. W., Jonas, T., Kim, E. J., Koch, I., Marty, C., Saloranta, T., Schöber, J. and De Lannoy, G. J. M.: Snow depth variability in the Northern Hemisphere mountains observed from space, Nature Communications, 10(1), 4629, 2019. 
https://doi.org/10.5194/tc-2021-139

Preprint. Discussion started: 17 May 2021

(c) Author(s) 2021. CC BY 4.0 License.

\section{(c) (i)}

Liston, G. E.: Representing Subgrid Snow Cover Heterogeneities in Regional and Global Models, J. Climate, 17(6), 13811397, 2004.

Liu, Y. and Margulis, S. A.: Deriving Bias and Uncertainty in MERRA-2 Snowfall Precipitation Over High Mountain Asia, Front. Earth Sci., 7, 39, doi:10.3389/feart.2019.00280, 2019.

515 Liu, Y., Fang, Y., and Margulis, S.A.: High Mountain Asia UCLA Daily Snow Reanalysis, Version 1. Boulder, Colorado USA, NASA Snow and Ice Data Center Distributed Active Archive Center, doi:10.5067/HNAUGJQXSCVU, 2021.

Lutz, A. F., Immerzeel, W. W., Shrestha, A. B. and Bierkens, M. F. P.: Consistent increase in High Asia's runoff due to increasing glacier melt and precipitation, Nature Clim Change, 4(7), 587-592, 2014.

Margulis, S. A., Girotto, M., Cortés, G. and Durand, M.: A Particle Batch Smoother Approach to Snow Water Equivalent 520 Estimation, Journal of Hydrometeorology, 16(4), 1752-1772, 2015.

Margulis, S. A., Cortés, G., Girotto, M. and Durand, M.: A Landsat-Era Sierra Nevada Snow Reanalysis (1985-2015), Journal of Hydrometeorology, 17(4), 1203-1221, 2016.

Margulis, S. A., Liu, Y. and Baldo, E.: A Joint Landsat- and MODIS-Based Reanalysis Approach for Midlatitude Montane Seasonal Snow Characterization, Front. Earth Sci., 7, 4257, doi:10.3389/feart.2019.00272, 2019.

525 Maussion, F., Scherer, D., Finkelnburg, R., Richters, J., Yang, W. and Yao, T.: WRF simulation of a precipitation event over the Tibetan Plateau, China - an assessment using remote sensing and ground observations, Hydrol. Earth Syst. Sci., 15(6), 1795-1817, doi:10.5194/hess-15-1795-2011, 2011.

Maussion, F., Scherer, D., Mölg, T., Collier, E., Curio, J. and Finkelnburg, R.: Precipitation Seasonality and Variability over the Tibetan Plateau as Resolved by the High Asia Reanalysis, J. Climate, 27(5), 1910-1927, doi:10.1175/JCLI-D-13$530 \quad 00282.1,2014$.

Mortimer, C., Mudryk, L., Derksen, C., Luojus, K., Brown, R., Kelly, R. and Tedesco, M.: Evaluation of long-term Northern Hemisphere snow water equivalent products, The Cryosphere, 14(5), 1579-1594, doi:10.5194/tc-14-1579-2020, 2020.

Mudryk, L. R., Derksen, C., Kushner, P. J. and Brown, R.: Characterization of Northern Hemisphere Snow Water Equivalent Datasets, 1981-2010, J. Climate, 28(20), 8037-8051, doi:10.1175/JCLI-D-15-0229.1, 2015.

535 Notarnicola, C.: Observing Snow Cover and Water Resource Changes in the High Mountain Asia Region in Comparison with Global Mountain Trends over 2000-2018, Remote Sensing, 12(23), 2020.

Orsolini, Y., Wegmann, M., Dutra, E., Liu, B., Balsamo, G., Yang, K., de Rosnay, P., Zhu, C., Wang, W., Senan, R. and Arduini, G.: Evaluation of snow depth and snow cover over the Tibetan Plateau in global reanalyses using in situ and satellite remote sensing observations, The Cryosphere, 13(8), 2221-2239, doi:10.5194/tc-13-2221-2019, 2019.

540 Osmanoglu, B., Painter, T. H., Shean, D., Arendt, A., Kargel, J. and Margulis, S. A.: Remote sensing of the cryosphere in high mountain ASIA, 2017 IEEE International Geoscience and Remote Sensing Symposium (IGARSS), 2813-2816, doi: 10.1109/IGARSS.2017.8127583, 2017

Painter, T. H., Dozier, J., Roberts, D. A., Davis, R. E. and Green, R. O.: Retrieval of subpixel snow-covered area and grain size from imaging spectrometer data, Remote Sensing of Environment, 85(1), 64-77, 2003. 
https://doi.org/10.5194/tc-2021-139

Preprint. Discussion started: 17 May 2021

(c) Author(s) 2021. CC BY 4.0 License.

Painter, T. H., Rittger, K., McKenzie, C., Slaughter, P., Davis, R. E. and Dozier, J.: Retrieval of subpixel snow covered area, grain size, and albedo from MODIS, Remote Sensing of Environment, 113(4), 868-879, 2009.

Painter, T. H., Brodzik, M. J., Racoviteanu, A. and Armstrong, R.: Automated mapping of Earth's annual minimum exposed snow and ice with MODIS, Geophys. Res. Lett., 39(20), 2012GL053340, doi:10.1029/2012GL053340, 2012.

Palazzi, E., Hardenberg, von, J. and Provenzale, A.: Precipitation in the Hindu-Kush Karakoram Himalaya: Observations and future scenarios, J. Geophys. Res. Atmos., 118(1), 85-100, doi:10.1029/2012JD018697, 2013.

Pfeffer, W. T., Arendt, A. A., Bliss, A., Bolch, T., Cogley, J. G., Gardner, A. S., Hagen, J.-O., Hock, R., Kaser, G., Kienholz, C., Miles, E. S., Moholdt, G., Mölg, N., Paul, F., Radić, V., Rastner, P., Raup, B. H., Rich, J. and Sharp, M. J.: The Randolph Glacier Inventory: a globally complete inventory of glaciers, Journal of Glaciology, 60(221), 537-552, 2014.

Pu, Z., Xu, L. and Salomonson, V. V.: MODIS/Terra observed seasonal variations of snow cover over the Tibetan Plateau, 555 Geophys. Res. Lett., 34(6), 32141, doi:10.1029/2007GL029262, 2007.

Pulliainen, J., Luojus, K., Derksen, C., Mudryk, L., Lemmetyinen, J., Salminen, M., Ikonen, J., Takala, M., Cohen, J., Smolander, T. and Norberg, J.: Patterns and trends of Northern Hemisphere snow mass from 1980 to 2018, Nature, 581(7808), 294-298, 2020.

Raup, B., Racoviteanu, A., Khalsa, S.-J. S., Helm, C., Armstrong, R. and Arnaud, Y.: The GLIMS geospatial glacier database: A new tool for studying glacier change, Global and Planetary Change, 56(1), 101-110, 2007.

RGI Consortium: Randolph Glacier Inventory - A Dataset of Global Glacier Outlines: Version 6.0: Technical Report, Global Land Ice Measurements from Space, Colorado, USA. Digital Media, https://doi.org/10.7265/N5-RGI-60, 2017

Rienecker, M. M., Suárez, M. J., Gelaro, R., Todling, R., Bacmeister, J., Liu, E., Bosilovich, M. G., Schubert, S. D., Takacs, L., Kim, G.-K., Bloom, S., Chen, J., Collins, D., Conaty, A., da Silva, A., Gu, W., Joiner, J., Koster, R. D., Lucchesi, R., 565 Molod, A., Owens, T., Pawson, S., Pegion, P., Redder, C. R., Reichle, R., Robertson, F. R., Ruddick, A. G., Sienkiewicz, M. and Woollen, J.: MERRA: NASA's Modern-Era Retrospective Analysis for Research and Applications, J. Climate, 24(14), 3624-3648, doi:10.1175/JCLI-D-11-00015.1, 2011.

Rodell, M., Houser, P. R., Jambor, U., Gottschalck, J., Mitchell, K., Meng, C. J., Arsenault, K., Cosgrove, B., Radakovich, J., Bosilovich, M., Entin, J. K., Walker, J. P., Lohmann, D. and Toll, D.: The Global Land Data Assimilation System, Bull. 570 Amer. Meteor. Soc., 85(3), 381-394, doi:10.1175/BAMS-85-3-381, 2004.

Rounce, D. R., Hock, R. and Shean, D. E.: Glacier Mass Change in High Mountain Asia Through 2100 Using the OpenSource Python Glacier Evolution Model (PyGEM), Front. Earth Sci., 7, 331, doi:10.3389/feart.2019.00331, 2020.

Scott, C. A., Zhang, F., Mukherji, A., Immerzeel, W., Mustafa, D. and Bharati, L.: Water in the Hindu Kush Himalaya, in The Hindu Kush Himalaya Assessment: Mountains, Climate Change, Sustainability and People, edited by P. Wester, A. 575 Mishra, A. Mukherji, and A. B. Shrestha, pp. 257-299, Springer International Publishing, Cham. 2019.

Sexton, J. O., Song, X.-P., Feng, M., Noojipady, P., Anand, A., Huang, C., Kim, D.-H., Collins, K. M., Channan, S., DiMiceli, C. and Townshend, J. R.: Global, 30-m resolution continuous fields of tree cover: Landsat-based rescaling of 
https://doi.org/10.5194/tc-2021-139

Preprint. Discussion started: 17 May 2021

(c) Author(s) 2021. CC BY 4.0 License.

(c) (i)

MODIS vegetation continuous fields with lidar-based estimates of error, International Journal of Digital Earth, 6(5), 427448, doi:10.1080/17538947.2013.786146, 2013.

Shean, D. E., Bhushan, S., Montesano, P., Rounce, D. R., Arendt, A. and Osmanoglu, B.: A Systematic, Regional Assessment of High Mountain Asia Glacier Mass Balance, Front. Earth Sci., 7, 363, doi:10.3389/feart.2019.00363, 2020.

Smith, T. and Bookhagen, B.: Assessing uncertainty and sensor biases in passive microwave data across High Mountain Asia, Remote Sensing of Environment, 181, 174-185, 2016.

Smith, T. and Bookhagen, B.: Changes in seasonal snow water equivalent distribution in High Mountain Asia (1987 to 2009), Sci Adv, 4(1), e1701550, 2018.

Smith, T. and Bookhagen, B.: Assessing Multi-Temporal Snow-Volume Trends in High Mountain Asia From 1987 to 2016 Using High-Resolution Passive Microwave Data, Front. Earth Sci., 8, 392, doi:10.3389/feart.2020.559175, 2020.

Sorg, A., Bolch, T., Stoffel, M., Solomina, O. and Beniston, M.: Climate change impacts on glaciers and runoff in Tien Shan (Central Asia), Nature Clim Change, 2(10), 725-731, 2012.

590 Stigter, E. E., Wanders, N., Saloranta, T. M., Shea, J. M., Bierkens, M. F. P. and Immerzeel, W. W.: Assimilation of snow cover and snow depth into a snow model to estimate snow water equivalent and snowmelt runoff in a Himalayan catchment, The Cryosphere, 11(4), 1647-1664, doi:10.5194/tc-11-1647-2017, 2017.

Sun, S. and Xue, Y.: Implementing a new snow scheme in Simplified Simple Biosphere Model, Adv. Atmos. Sci., 18(3), 335-354, 2001.

595 Tahir, A. A., Chevallier, P., Arnaud, Y. and Ahmad, B.: Snow cover dynamics and hydrological regime of the Hunza River basin, Karakoram Range, Northern Pakistan, Hydrol. Earth Syst. Sci., 15(7), 2275-2290, doi:10.5194/hess-15-2275-2011, 2011.

Takala, M., Luojus, K., Pulliainen, J., Derksen, C., Lemmetyinen, J., Kärnä, J.-P., Koskinen, J. and Bojkov, B.: Estimating northern hemisphere snow water equivalent for climate research through assimilation of space-borne radiometer data and ground-based measurements, Remote Sensing of Environment, 115(12), 3517-3529, 2011.

Terzago, S., Hardenberg, von, J., Palazzi, E. and Provenzale, A.: Snowpack Changes in the Hindu Kush-KarakoramHimalaya from CMIP5 Global Climate Models, Journal of Hydrometeorology, 15(6), 2293-2313, doi:10.1175/JHM-D-130196.1, 2014.

Wang, X., Wu, C., Wang, H., Gonsamo, A. and Liu, Z.: No evidence of widespread decline of snow cover on the Tibetan 605 Plateau over 2000-2015, Nature Publishing Group, 7(1), 14645, 2017.

Winiger, M., Gumpert, M. and Yamout, H.: Karakorum-Hindukush-western Himalaya: assessing high-altitude water resources, Hydrol. Process., 19(12), 2329-2338, doi:10.1002/hyp.5887, 2005.

Wrzesien, M. L., Pavelsky, T. M., Durand, M. T., Dozier, J. and Lundquist, J. D.: Characterizing Biases in Mountain Snow Accumulation From Global Data Sets, Water Resour. Res., 55(11), 9873-9891, doi:10.1029/2019WR025350, 2019. 
https://doi.org/10.5194/tc-2021-139

Preprint. Discussion started: 17 May 2021

(c) Author(s) 2021. CC BY 4.0 License.

610 Xue, Y., Sun, S., Kahan, D. S. and Jiao, Y.: Impact of parameterizations in snow physics and interface processes on the simulation of snow cover and runoff at several cold region sites, J. Geophys. Res., 108(D22), doi:10.1029/2002JD003174, 2003.

Xue, Y., Houser, P. R., Maggioni, V., Mei, Y., Kumar, S. V. and Yoon, Y.: Assimilation of Satellite-Based Snow Cover and Freeze/Thaw Observations Over High Mountain Asia, Front. Earth Sci., 7, 872, doi:10.3389/feart.2019.00115, 2019.

615 Yao, T., Thompson, L., Yang, W., Yu, W., Gao, Y., Guo, X., Yang, X., Duan, K., Zhao, H., Xu, B., Pu, J., Lu, A., Xiang, Y., Kattel, D. B. and Joswiak, D.: Different glacier status with atmospheric circulations in Tibetan Plateau and surroundings, Nature Clim Change, 2(9), 663-667, 2012. 